\title{
Contribution to the knowledge of algae of Nigeria. I. Desmids from the Warri/Forcados Estuaries. Part II. The elongate baculiform desmids
}

\author{
Fred. Idiem' OPUTE \\ Phycology and Phytoplankton Laboratory, Department of Botany, University of Benin, Benin City, Nigeria \\ e-mail address: fiopute@uniben.edu
}

\begin{abstract}
The freshwater zones of the Warri/Forcados Estuaries contain a rich and diverse flora of tropical desmids, which compare favourably and show strong affinities with desmids from other parts of Africa, tropical South America, Southeast Asia, tropical Australia and the Indian sub-continent. In this study, ninety (90) taxa belonging to seventeen (18) elongate baculiform and colonial genera are described. Fifty (50) of the taxa have been described for the first time for Nigeria, while nineteen (19) of them are new to Africa. Part 1 in this series of studies was devoted to the desmid genera Euastrum and Micrasterias. Based on new findings, a new taxon, Pleurotaenium subcoronulatum (Turner) W. West \& G.S. West var. spinulosum Opute var. nova. has been proposed.
\end{abstract}

Key words: algae, desmids, phytoplankton, freshwater, estuaries, tropical, Nigeria

\section{INTRODUCTION}

The author, between 1984-87, investigated the phytoplankton flora of the Warri/Forcados Estuaries and in his preliminary publication (Opute 1985) reported the presence of a number of desmids in the potamoplankton of the freshwater zones of the estuaries. Fascinated by the sheer beauty and symmetry of these plants, a more detailed study of the desmids was embarked upon. The first part of this detailed study, which focused on the two desmids genera Euastrum and Micrasterias, was reported in Opute (1992). Hitherto desmid studies in Nigeria had received little attention. The only reported works of interest were those of Khan (1984), who described some desmids from the Jos Plateau of Northern Nigeria, Kadiri $(1987,1988)$ who reported on the desmids of Ikpoba Reservoir, and Kadiri \& Opute (1989) on the Micrasterias species of the Ikpoba Reservoir.

However, in the past 3 decades, substantial studies have been carried out on the desmid flora of tropical countries. In Asia Agarkar (1969, 1971), Bharati \& Pai (1972), Sinha \& Mishra (1967), Suxena \& Venkateswarlu (1970), Vidyavati \& Nizam (1970) all from India; Islam (1970), Islam \& Zaman (1975), Islam \& Haroon (1980, 1985) from Bangladesh; Hirano (1972) from Cambodia and Thailand; Scott \& Prescott (1961) from Indonesia; in South America the works of Bicudo (1969), Forster (1963, 1969), Scott, Grönblad and Croasdale (1965) from Brazil; Parra (1975) from Chile; Yacubson (1973) from Venezuela; in Central America the work of Prescott (1966) from Panama; in Africa the works of Bourrelly (1957, 1961), Forster (1964), Grönblad (1962), Grönblad, Prowse and Scott (1958), Grönblad, Scott \& Croasdale (1964, 1968), Lind (1967, 1971), Thomasson $(1960,1965,1966)$, and Compere
(1967, 1977), Coute \& Rousselin (1975) and Gerrath \& John (1988) are worthy of mention.

A close scrutiny of the African studies clearly shows that the regions covered are mostly in Central and Eastern Africa. The West Coast with a somewhat different geography and geology has not been critically and exhaustively investigated. The present study, which aims at contributing to closing this gap, is devoted to the ten elongate baculiform genera of Gonatozygon (6), Genicularia (1), Spirotaenia (1), Cylindrocystis (2), Netrium (1), Penium (3), Closterium (39), Pleurotaenium (18), Triploceras (1) and Tetmemorus (1), as well as the seven elongate colonial genera of Sphaerozosma (2), Spondylosum (2), Onychonema (1), Hylotheca (2), Phymatodocis (1), Bambusina (2) and Desmidium (6), including the colonial genus Cosmocladium (1). The figures in bracket indicate the number of taxa.

\section{THE STUDY AREA}

Figure 1a represents the Warri/Forcados Estuaries of Southern Nigeria. Located between latitude $5^{\circ}$ and $6^{\circ}$ North and longitude $5^{\circ}$ and $6^{\circ}$ East, the study area forms part of the anastomosing creeks traversing the Southern coastline of Nigeria. It is derived from the merging and convergence of the Warri and Forcados rivers and their tributaries. From an average width of about $100 \mathrm{~m}$ in the narrowest parts, it spans over $3 \mathrm{~km}$ in the widest regions before emptying into the Atlantic Ocean at South Point within the Bight of Benin.

The drainage basin is typically of rain forest formation and covers approximately $2627 \mathrm{~km}^{2}$. The entire waterway, which is over $80 \mathrm{~km}$ long, is affected by strong tidal action especially in the dry season months. Apart from the typical mangrove trees, the other fringing vegetation included swamp trees interspersed with 

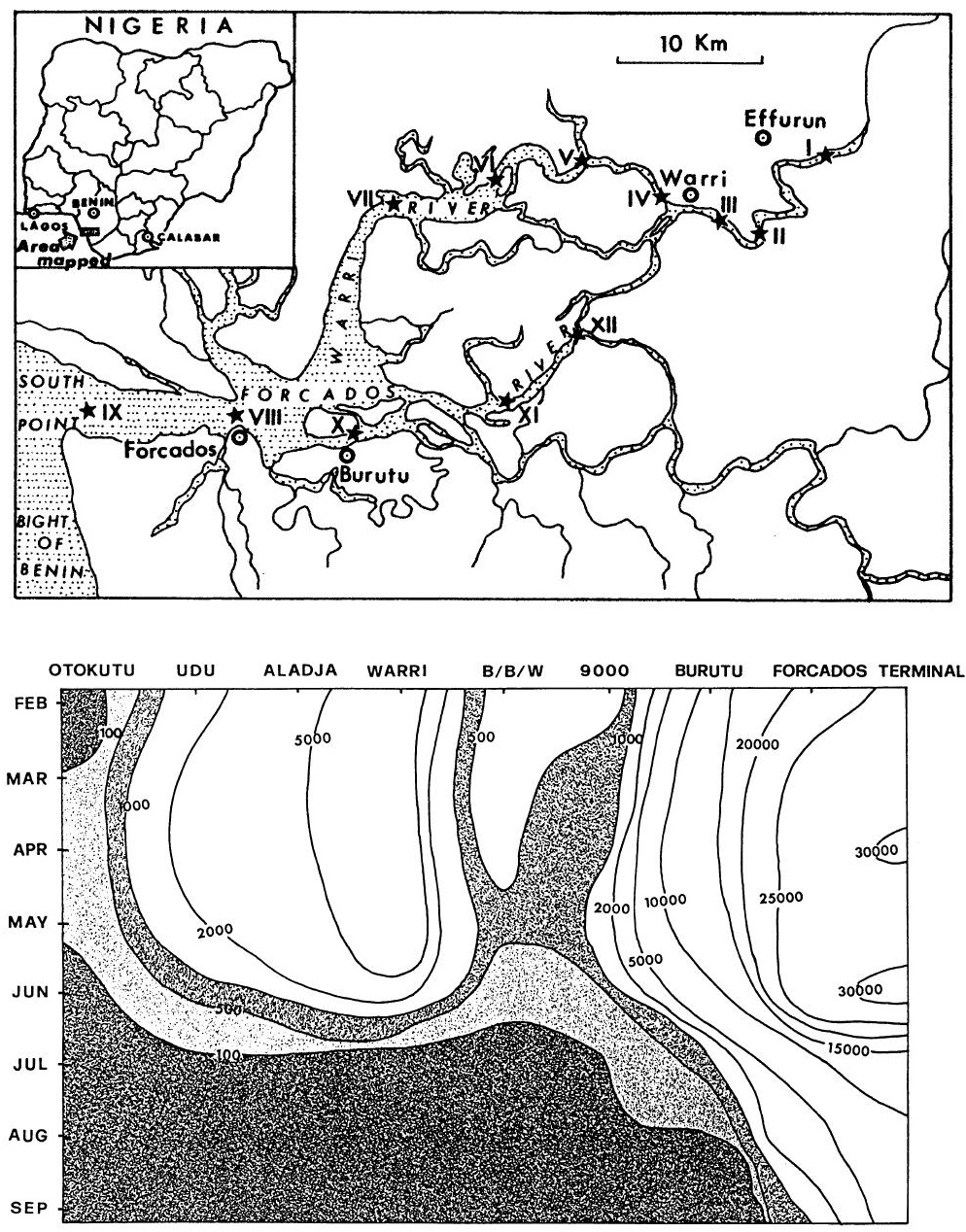

Fig. 1a. Map of the Warri/Forcados Estuaries showing the sampling stations. I. Otokutu; II. Udu Bridge; III. Aladja; IV. Warri Port; V. Ejere; VI. Bennet Island; VII. Bouy 4; VIII. Forcados Town; IX. Forcados Terminal; X. Burutu; XI. Point 9000; XII. Bomadi.Burutu/Warri (B/B/W) Junction.

Fig. 1b. The conductivity isopleths of the Warri/Forcados Estuaries along the sampling route. The shaded areas below $500 \mu \mathrm{S} \mathrm{cm}{ }^{-1}$ indicate freshwater zones. grasses, ferns and various emergent macrophytes. The area enjoys a tropical climate, with well demarcated rainy and dry seasons. The dry season stretches from November to April while the rainy season is usually from May to October. The average annual rainfall is $2500 \mathrm{~mm}$, while the mean maximum hourly rainfall is $100 \mathrm{~mm}$ (S.P.D.C. 1988). The minimum air temperature recorded is $18{ }^{\circ} \mathrm{C}$, while the maximum is $35^{\circ} \mathrm{C}$, with a mean minimum ambient of $23{ }^{\circ} \mathrm{C}$ and a mean maximum ambient of $31^{\circ} \mathrm{C}$.

The $500 \mu \mathrm{S} \mathrm{cm}^{-1}$ conductivity isopleth, roughly approximating to $0.5 \%$ salinity, served to demarcate the true freshwater zone from brackish water. The freshwater zone was further divided into two sub-zones - an area of less than $100 \mu \mathrm{S} \mathrm{cm}^{-1}$ and another between 100 and $500 \mu \mathrm{S} \mathrm{cm}^{-1}$. A mixing zone of between 500 and $1000 \mu \mathrm{S} \mathrm{cm} \mathrm{cm}^{-1}$ formed the transition band between freshwater and brackish water (Fig. 1b).

The extent of distribution of freshwater along the estuaries at any time of the year was found to be variable and closely correlated with the geographical position of the transition zone between the saline and freshwater zones. This zone is affected by the interplay between the tidal range and the volume of water discharge or runoff. The transition zone is near the mouth of the estuary when there is a relatively small tidal range and a large runoff; it is near the headwaters or source when there is a large tidal range and a small runoff. As the rains come with higher precipitation, the volume of river discharge increases and the transition zone gradually moves downstream until over $80 \%$ of the estuary are occupied by freshwater between the months of July and October.

Although the freshwater zone is limited to areas below $500 \mu \mathrm{S} \mathrm{cm}{ }^{-1}$ conductivity, the major sectors in which desmids were found were limited largely to waters below $100 \mu \mathrm{S} \mathrm{cm}$. These areas stretched from Udu Bridge to Ejere in the Warri River (Stations II, III, $\mathrm{IV}, \& \mathrm{~V}$ ) and from Burutu to B/B/W (stations X-XII) in the Forcados River (Stations X, XI, \& XII) (Fig. 1b).

\section{MATERIALS AND METHODS}

Plankton collections were carried out in the peak of the rainy season (months) between July and October 1985-1987 when water discharge was at its highest and the rivers were fully flooded with minimal current flow. 
Collections were made in the open water with phytoplankton tow nets of $55 \mu \mathrm{m}$ mesh. The net catches were transferred into collection bottles and immediately preserved with $4 \%$ formalin.

Aliquots of the samples were examined, and photomicrographs and illustrations made with both a Leitz Orthoplan Wide field Research Microscope equipped with a Vario-Orthomat Camera and tracing device, and a Zeiss Research Microscope with an MC63 automatic camera and a drawing tube. Identifications were made, by reference to standard works especially the following monographs - Krieger (1937, 1939), Ruzicka (1977, 1981), Prescott, Croasdale \& Vinyard (1975), Prescott et al. $(1981,1982)$, Lind \& Brook (1980) and G. HuberPestalozzi (1982) and numerous journal publications.

\section{LIMNOLOGY OF THE ESTUARIES}

The physico-chemical parameters of the estuaries varied typically from month to month depending mainly on the season and the tidal influence. However, in the rainy season, conditions were relatively stable in the experimental stations. Water level was at its peak with the river current at its minimal flow rate. Conductivity values, measured at ambient temperature, were between 18 and $60 \mu \mathrm{S} \mathrm{cm}^{-1}$; dissolved oxygen varied between 2.5 and $4.5 \mathrm{mg} \mathrm{l}^{-1}$ while total alkalinity values as $\mathrm{CaCO}_{3}$ were as low as $4.0 \mathrm{mg} \mathrm{l}^{-1}$ in the headwaters (Udu Bridge) and as high as $22 \mathrm{mg} \mathrm{l}^{-1}$ downstream at Burutu. Water transparency in all stations except in Udu Bridge was below $50 \mathrm{~cm}$.

Recorded $\mathrm{pH}$ values were between 5.5 and 7.3. Total nitrogen and dissolved nitrate were generally low and in all cases were below $0.1 \mathrm{mg} \mathrm{l}^{-1}$ throughout the period of study. The daytime temperatures fluctuated between 25 and $34{ }^{\circ} \mathrm{C}$ throughout the period. In the rainy season the water body was more oligotrophic than the rather eutrophic characteristic in the dry season. The averages of some physico-chemical values are given in the table 1 .

The Warri/Forcados Estuaries constitute a major distributary of the River Niger which experiences high flood season between June and October each year. The silt laden flood has been shown to depress water conductivity to levels below $90 \mu \mathrm{S} \mathrm{cm}-1$ and reduce water transparency to less than $50 \mathrm{~cm}$ (John 1986). In addition to low conductivity of the waters, $\mathrm{pH}$ is usually acidic to neutral. From a chemical point of view, the waters of the estuaries showed peculiarly low levels of dissolved oxygen (Tab. 1). The low oxygen concentration may be due to either or a combination of the following factors:

- low primary production caused by low water transparency and low nutrient load or

- increased and rapid organic decomposition of plant debris enhanced by high temperatures.

It has been suggested that plankton of oligotrophic water bodies are characterised by a large number of desmid species (Brook 1965). The abundance and variety of desmid species found in the Warri/Forcados Estuaries is therefore not surprising.

\section{TAXONOMY AND DESCRIPTION OF SPECIES}

All dimensions are given in micrometer $(\mu \mathrm{m}) . \mathrm{L}=$ length of cell; $\mathrm{W}=$ maximum width of cell; $\mathrm{Wa}=$ width at apex; I = width of isthmus. The magnifications are as indicated in the plates for photomicrographs, while they are represented by bar lines under the figures, each bar line equal to $20 \mu \mathrm{m}$. Taxa indicated by an asterisk are reported for Nigeria for the first time while double asterisks represent those new to Africa.

\subsection{Key to desmid genera of Warri/Forcados Estuaries reported in this paper}

1a Cells solitary and cylindrical

2a. Cell wall always in one piece, without pores and ornamentation; without median constriction.

3a. Cells with parietal spirally wound chloroplast. Spirotaenia

3b. Chloroplast either plate-like or star-like; typically two in each cell.

4a. Cells small and short, less than $3 x$ longer than broad; chloroplast without

notched ridges Cylindrocystis

4b. Cells large and elongate, more than $3 x$ longer than broad; chloroplast with notched ridges Netrium

2b. Cell wall always in 2 or more pieces; wall with pores and sometimes ornamentation.

5a. Cells mostly more than $3 x$ longer than broad;

Tab. 1. Some physical and chemical parameters of the freshwater zones of the Warri/Forcados Estuaries.

\begin{tabular}{lcccccc}
\hline Station & $\begin{array}{c}\text { Conductivity } \\
\left(\mu \mathrm{S} \mathrm{cm}^{-1}\right)\end{array}$ & $\begin{array}{c}\text { Diss. } \mathrm{O}_{2} \\
\left(\mathrm{mg} \mathrm{l}^{-1}\right)\end{array}$ & $\mathrm{pH}$ & $\begin{array}{c}\text { Alkalinity } \\
\left(\mathrm{mg} \mathrm{l}^{-1}\right)\end{array}$ & $\begin{array}{c}\text { Temperature } \\
\left({ }^{\circ} \mathrm{C}\right)\end{array}$ & $\begin{array}{c}\text { Transparency } \\
(\mathrm{cm})\end{array}$ \\
\hline Udu Bridge & $18-24$ & 3.0 & 5.8 & 4 & 30 & 51 \\
Aladja & $23-33$ & 3.5 & 6.1 & 7 & 29 & 45 \\
Warri & $39-50$ & 3.4 & 7.3 & 16 & 32 & 36 \\
Ejere & $45-57$ & 3.4 & 7.3 & 20 & 27 & 29 \\
B/B/W & $38-45$ & 3.2 & 7.0 & 19 & 31 & 28 \\
9000 & $39-45$ & 3.3 & 7.0 & 20 & 29 & 21 \\
Burutu & $45-59$ & 4.3 & 7.1 & 22 & 27 & 19.5 \\
\hline
\end{tabular}


cell wall unconstricted in the middle.

6a. Cells mostly lunate or curved and usually tapered to the apices; wall smooth and striate Closterium

6b. Cells straight; walls often granular.

7a. Cells mostly in loose filament; cells more than $7 \mathrm{x}$ longer than broad; apices usually broadened or expanded.

8a. Chloroplasts single and axile

8b. Chloroplasts 2-3, parietal and spiralled Gonatozygon

7b. Cells not in filaments, mostly $3-15 x$ longer than broad; apices not expanded Genicularia

5b. Cells constricted in the middle

9a. Apex truncate or rounded

9b. Apex excavate, notched or incised

10a. Apex excavate; wall with whorls of simple or cleft spines Triploceras

10b. Apex notched or incised; whorls of spines absent Tetmemorus

1b. Cells in colonies

11a. Colonies filamentous; cells united by special apical interlocking processes Sphaerozosma

12a. Processes overlapping adjacent cells Onychonema

12b. Colonies filamentous; cells not united by special apical processes

13a. Cells without infolded thickening at point of division

14a. Semicells not lobed in end view

15a. Cells deeply constricted ................... Spondylosum

15b. Cells not deeply constricted; usually about as long as broad; chloroplast stellate Hylotheca

13b. Cells with an infolded thickening at the point of division

16a. Cells elongate and cylindrical Bambusina

16b. Cells short, fusiform triangular or quadrangular in vertical view ...............Desmidium

14b. Semicells 4-lobed in end view ......... Phymatodocis

11b. Colonies not filamentous; Cosmarium-like cells not in contact but joined by gelatinous strands Cosmocladium

\section{Genus GONATOZYGON De Bary (1856)}

Gonatozygon aculeatum Hastings (1892)

L. 354-359; W. 25-28; P1. 1: 1; Fig. 5: 1.

Cells elongate-cylindrical, straight with slightly dilated apices, 15-18 times longer than broad; cell wall covered by long needle-like spines; chloroplasts of two parietal bands with a number of pyrenoids. Cf. Forster (1969, Pl. 1: 30-32), Forster (1982, Pl. 2, Figs 1-4), Croasdale \& Flint (1986, Pl. 2, Figs 1, 2) and Gerrath \& John (1988, Pl. 2, Fig. 21).

**Gonatozygon kinahanii (Archer) Rabenhorst. var. interruptum Forster (1969)

\section{389-412; W. 26-30; Pl. 1: 2, 3}

Cells subcylindrical, relatively stout, rarely straight, usually crooked or bent; 13-16 times longer than broad, slightly dilated at the apex; chloroplast flat with a number of constrictions and a string of pyrenoids. Cf. Forster (1969, Pl. 1, Figs 15, 16).

**Gonatozygon kinahanii (Archer) Rabenhorst f. minor Forster (1969)

L. 163-173; W. 11-16; Pl. 1: 4, 5; Fig. 5: 4

Cells cylindrical and relatively short, about 12 times longer than broad; chloroplast, ribbon-like and some what twisted; 7-9 pyrenoids in each semi-cell; cell wall hyaline and smooth. The present plants are similar to the forms described by Forster (1969, Fig. 1:10,11).

*Gonatozygon monotaenium De Bary (1856) W. \& G.S. West (1904)

L. 334-340; Wc. 19-20; Wa. 21-22. Pl. 1: 6

Cells elongate and usually straight and narrow, about 18 times longer than broad and slightly dilated at the apices. The Warri/Forcados specimens are much larger than most reported plants. Cf. Forster (1969, Fig. 1:18, 19); Scott \& Prescott (1961). The latter authors however found a single large specimen from their Java collections similar in size to the present plants.

**Gonatozygon monotaenium De Bary var. angustum Forster (1969)

L. 239-262; W. 12-13; Pl. 1: 7, 8; Fig. 5: 5

Cells elongate, subcylindrical and narrow, virtually straight, 20-23 times longer than broad; chloroplast, flat and ribbon-shaped. Cf. the plant described by Forster (1969, Pl. 1, Figs 20, 21) for desmids from the Amazon.

*Gonatozygon pilosum Wolle (1882)

L. 330-396; W. 15-18; $\quad$ Fig. 5: 2, 3.

Cells long and slender, rarely straight, usually bent, 2325 times longer than broad; neither tapered nor dilated at the truncately rounded apices; chloroplast ribbon-like and stringed with pyrenoids; wall densely covered with small, straight, hair-like spines. Cf. Forster (1969, Pl. 1: 28, 29), Forster (1982, Pl. 2, Fig. 9) and Croasdale \& Flint (1986, Pl. 2, Figs 12, 13).

\section{Genus GENICULARIA De Bary 1858}

* Genicularia elegans W. West \& G.S. West (1859)

L. 350-548; W. 33-35. Pl. 1: 9

Cells cylindrical, 10-17 times longer than broad; apices truncate and slightly broadened; cells either solitary or sometimes remain attached end to end in filaments, but separating and becoming geniculate before conjugation; walls granulate; chloroplasts of two continuous parietal bands, usually making 1-2 spiral turns, each band with numerous pyrenoids. Cf. Ruzicka (1977, Pl. 2: 26, 27) and Forster (1982, Pl. 3, Figs 3, 4).

\section{Family MESOTAENIACEAE}

Genus SPIROTAENIA Brebisson 1844 
Spirotaenia condensata Brebisson in Ralfs (1848)

L. 166-180; W. 17-20; Pl. 1: 14; Fig. 4: 11

Cells long and cylindrical, slightly curved, rarely straight; 8-10 times longer than broad; margins parallel, circular in cross-section; apex tapering to a rounded end; membrane smooth without pores; chloroplast unique, a broad parietal band consisting of about 12 close spirally wound turns; pyrenoids few to many. The present plants are much larger than the ones reported by Forster (1969, Pl. 1, Fig. 1), Forster (1982, Pl. 1, Figs 15, 16) and Croasdale \& Flint (1986, Pl. 1, Figs 11, 12).

\section{Genus CYLINDROCYSTIS Menegh. (1838)}

Cylindrocystis brebissonii Menegh. (1838)

L. 42-64; W. 15-25. Fig. 4: 12, 13

Cells showing variation in size and shape with many intergrading forms; cylindrical with broadly rounded apices; about 2.5 times longer than broad; chloroplast axile, usually with a few large rays, and a central elongate pyrenoid. Cf. Scott \& Prescott (1961, Pl. 1, Fig. 3), Croasdale \& Grönblad (1964, Pl.1, Figs 8-11), Scott et al. (1965, Fig. 1), Grönblad et al. (1968, Fig. 1), Forster (1982, Pl. 1, Figs 1-3), Croasdale \& Flint (1986, P1. 1, Figs 15, 16) and Gerrath \& John (1988, Pl. 2, Fig. 1).

\section{Genus NETRIUM (Naegeli) Itzigsohn \& Rothe (1856)}

Netrium digitus (Ehr.) Itzigsohn \& Rothe var. lamellosum (Brebisson) Grönblad (1920)

\section{260-263; W. 43-44; Pl. 1: 13; Fig. 4: 16.}

Cells large, naviculoid or elliptic-fusiform, about 6 times longer than broad; lacks median constriction; lateral margins retuse in the mid-region, attenuating to truncately rounded apices; cell wall smooth; two large chloroplasts, one in each half of the cell, strongly dissected at the margins with a single elongate pyrenoid. Cf. Croasdale \& Grönblad (1964, P1. 1, Fig. 21), Grönblad et al. (1968, Fig. 3), Islam \& Haroon (1980, P1. 2, Fig. 27), Forster (1982, Pl. 1, Fig. 8), Croasdale \& Flint (1986, Pl. 4, Fig. 1) and Ling \& Tyler (1986, Pl. 6:7).

\section{Family DESMIDIACEAE}

\section{Genus PENIUM (Brebisson) Ralfs (1848)}

Penium cylindrus (Ehrenberg) Brebisson in Ralfs (1848) L. 68-70; W. 17-19; I. 14-15; Pl. 1: 10

Cells short and cylindrical, about 4 times longer than broad, with a slight median constriction; semi-cell with parallel sides, broadening slightly towards a truncate apex; cell wall reddish brown in colour. My plants are larger than the species described by Scott \& Prescott (1958, Pl. 1, Fig. 20), Scott \& Prescott (1961, P1. 1, Fig. 11), Forster (1969, Pl. 2:3-6), Forster (1982, Pl. 2, Figs 15-17) and Ling \& Tyler (1986, Pl. 6: 13, 14). Cf. the plant described by Thomasson (1965, Fig. 5:4) as $P$. margaritaceum (Ehrenberg) Brebisson.

Penium margaritaceum (Ehrenberg) ex Brebisson in Ralfs (1848)
L. 150-153; W. 29-31; I. 27-28; Pl. 1: 12; Fig. 5: 10 Cells subcylindrical, of medium size, about 5 times longer than broad; slightly discernible median constriction; semi-cells tapering gradually towards truncately rounded apices; transverse girdle bands present. Cf. Grönblad et al. (1968, Fig. 7), Lind (1967, Pl. 1, Figs 1, 2), Forster (1982, Pl. 2, Fig. 14) and Croasdale \& Flint (1986, P1. 3, Figs 13-15).

\section{**Penium spinulosum (Wolle) Gerrath (1969)}

L. 374-475; W. 40-44; P1. 1: 11; Fig. 6: 10

Cells cylindrical and elongate, about 10 times longer than broad, slight median constriction; semi-cell strongly crenate, with two basal inflations, a number of undulations and slightly tapered at the apex; girdle bands present; cell wall with dense prominent needle-like spines and reddish brown in colour. This interesting desmid was limited in distribution to between Udu Bridge and Ejere on the Warri River Estuary. The plant was first described by Wolle (1881) as Docidium spinulosum and later changed to Pleurotaenium spinulosum by Brunnel (1949). Based on ultrastructural studies using electron microscopy, Gerrath (1969, fig. 4) showed that the taxon belonged to the genus Penium and so renamed it. The present find is the first report of the desmid in mainland Africa, a varietal form having been earlier reported from Madagascar by Brunnel (1949) as Pleurotaenium spinulosum. This is a rare desmid; in localities where this species has been reported in the United States, Canada, and Madagascar and recently in Australia, only a few specimens were seen. A significant difference between Gerrath's plants and those in this collection is the number of undulations per semi-cell; Gerrath's plants had 7 undulations while the Warri River plants had between 10 and 14 undulations per semi-cell, thus resembling more closely the Australian form reported by Thomasson (1973, Figs 1, 2). Like the Australian desmid the spines of the present plants are shorter, denser and triangular.

\section{Genus CLOSTERIUM (Nitzsch) Ralfs 1844}

This is a widely distributed genus, a large number being truly planktonic. Many occur in acidic waters and others appear to tolerate highly eutrophic or even polluted waters. Cells solitary, never medianly constricted, elongate, mostly regularly curved, and tapered towards both ends; cells usually several times longer than broad (2150 times actually reported from literature). In size, from less than 10 to more than $1000 \mu \mathrm{m}$ long; cell wall mostly colourless, sometimes pale yellow to reddishbrown as a result of impregnation with iron compounds; smooth or striate, always with pores which are sometimes discernible; some have girdle bands, usually two in a cell which mark where a new section of the cell wall has been interpolated between the two ends just before vegetative cell division; semi-cells with a single axile chloroplast, showing longitudinal ridges and one to many large pyrenoids, usually in the median row, but in larger species scattered. Polar (apical) region often with 
a large terminal vacuole containing one to many crystals, recently identified as barium sulphate (Brook et al. 1980), and exhibiting Brownian movement. Curvature, important in identification, is given in degrees of arc and is measured by superimposing a "Closterio-curvimeter", a device of Hemians (1946), over a drawing or photograph of the Closterium cell.

Closterium acerosum (Schroeder) Ehrenberg (1828)

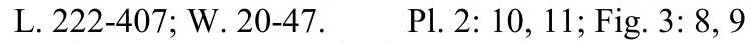
Cells fusiform, variable in size, almost straight with rounded truncate apices; curvature $30-36^{\circ}$ of arc; wall finely striate, yellowish-brown or colourless; chloroplasts ridged with 7-8 pyrenoids. Cf. van Oye (1953, Fig. 4), Scott \& Prescott (1961, Pl. 3, Fig. 1) Croasdale \& Grönblad (1964, P1. 3, Fig. 17), Ling \& Tyler (1986, Pl. 8: 5-7) and Gerrath \& John (1988, Pl. 9, Fig. 1).

*Closterium acerosum (Schroeder) Ehrenberg var. elongatum Brebisson (1856)

L. 713-814; W. 49-53. Fig. 4: 6

Cells 14-16 times longer than broad and much larger than the typical species; little curved, less than $30^{\circ}$ of arc; striolate, 9-11 striae in $10 \mu \mathrm{m}$. Cf. van Oye (1953, Fig. 5) and Forster (1982, Pl. 7, Fig. 3).

\section{*Closterium aciculare T. West (1860)}

\section{644-852; W. 11-13. Pl. 2: 1, 2; Fig. 2:10, 11}

Cells exceedingly long and narrow, 59-66 times longer than broad; slightly curved, gradually and almost imperceptibly attenuated from the middle to the slightly incurved, acutely rounded apices; chloroplasts do not extend into the apices; cell wall smooth and colourless. Cf. Scott \& Prescott (1958, Fig. 1:1), Grönblad et al. (1964, Figs 159, 160), Lind (1967, p. 365), Forster (1969, Pl. 2: 20) and Croasdale \& Flint (1986, Pl. 5, Figs 1-3).

\section{*Closterium baillyanum Brebisson in Ralfs (1848) \\ L. 237-260; W. 15-17. Fig. 2: 20}

Cells long and slender, slightly curved, $20-30^{\circ}$ of arc; margins parallel and attenuated at the poles towards obliquely rounded apices; wall pale yellow in colour and punctate and sometimes with girdle bands. Cf. Scott \& Prescott (1961, P1. 2, Fig. 21), Scott et al. (1965, Fig. 18), Ruzicka (1977, Pl. 23: 5, 6) and Forster (1982, Pl. 5, Fig. 12).

\section{Closterium calosporum Wittrock (1869)}
L. 130-145; W. 14-16.
Pl. 2: 17

Cells 9-10 times longer than broad; moderately curved, $100-110^{\circ}$ of arc; ventral margin almost straight in the middle portion, thereafter attenuated to obliquely rounded apices; cell wall smooth; chloroplast with 4-6 pyrenoids in each semi-cell. Cf. Forster (1969, Pl. 2: 26, 27).

Closterium costatum Corda var. westii Cushman (1908) L. 196-286; W. 24-28. Pl. 3: 1

Cells slightly curved, $25-30^{\circ}$ of arc; slightly swollen in the midregion at the concave side; apex broad and flat; cell wall dark brown in colour with a number of costae, more prominent towards the poles. Cf. Irenee-Marie (1939, P1. 7, Figs 5, 6), Prescott et al. (1975, Pl. 33, Figs 6,7), Ruzicka (1977, Pl. 27: 16), Islam \& Haroon (1980, Pl. 2, Fig. 24) and Kadiri (1988, Fig. 2b)

Closterium cynthia De Notaris (1867)

L. 86-188; W. 14-19; P1. 2: 16 .

Cells 7-10 times longer than broad, strongly curved, $110-145^{\circ}$ of arc; in most cases with a straight parallel median portion, thereafter gradually and evenly attenuated to bluntly rounded apices; wall with true girdle bands, conspicuously striate (8-12 striae in $10 \mu \mathrm{m})$ and yellowish-brown in colour; chloroplast with 3-6 pyrenoids. Cf. Scott \& Prescott (1958, Fig. 1: 7), Croasdale \& Grönblad (1964, Pl. 5, Fig. 4), Lind (1967, Pl. 1, Fig. 5), Grönblad et al. (1968, Fig. 26), Forster (1969, Pl. 3: 11-13), Forster (1982, Pl. 1.9, Figs 5, 6). and Ling \& Tyler (1986, Pl. 5: 21).

\section{Closterium dianae Ehrenberg (1838)}

L. 263-298; W. 19-26. Pl. 2: 13; Fig. 4: 3

Cells 15-17 times longer than broad; strongly curved, $110-120^{\circ}$ of arc; ventral margin concave, in most cases slightly tumid in the mid-region, tapering to obliquely truncate apices; cell wall smooth; chloroplast with 5-7 pyrenoids per semi-cell. Cf. Scott \& Prescott (1958, Pl. 1: 3), Croasdale \& Grönblad (1964, Pl. 3, Fig. 3), Forster (1969, Pl. 3: 4, 5), Islam \& Haroon (1980, Pl. 2, Figs 29, 30), Croasdale \& Flint (1986, Pl. 7, Figs 3, 4) and Gerrath \& John (1988, Pl. 4, Fig. 1).

**Closterium dianae Ehrenberg var. arcuatum (Brebisson) Rabenhorst (1868)

L. 270-320; W. 17-36. P1. 2: 15; Fig. 3: 10

Cells strongly curved, $115-145^{\circ}$ of arc; ventral margin concave, gradually attenuated towards the obliquely truncated apices; cell wall smooth and pale yellow in colour; chloroplast with 5-9 pyrenoids. Cf. Scott \& Prescott (1958, Fig. 1: 4), Croasdale \& Grönblad (1964, Pl. III, Fig. 4-5), Croasdale \& Flint (1986, p. 58) and Ling \& Tyler (1986, P1. 5: 22).

*Closterium dianae Ehrenberg var. pseudodianae (Roy) Krieger (1937)

L. 256-299; W. 15-20. $\quad$ P1. 2: 14

Cells differ from earlier reported forms in its lesser curvature, from $105-115^{\circ}$ of arc, and being narrower and tapered at the apices; chloroplast 8-10 pyrenoids. Cf. Scott \& Prescott (1961, Pl. 2, Fig. 7), Forster (1982, Pl. 9, Figs 10, 11) and Croasdale \& Flint (1986, Pl. 7, Fig. 6).

\section{**Closterium eboracense (Ehrenberg) Turner (1892)}

L. 308-320; W. 67-72. Fig. 3: 11

Cells very stout and tumid, 4-5 times longer than broad; moderately curved, about $90^{\circ}$ of arc; ventral margin concave, cell gradually attenuated to broadly rounded apices; chloroplast with a number of ridges, each con- 
taining 5-8 pyrenoids. Cf. Croasdale \& Grönblad (1964, Pl. 2, Fig. 28).

Closterium ehrenbergii Meneghini ex Ralfs (1848)

L. 407-480; W. 70-74. Pl. 3: 9,10; Fig. 3: 4, Fig. 4:

1,2

Cells stout and large, strongly curved, $115-140^{\circ}$ of arc; tumid at the mid-region, narrowing progressively to broadly rounded apices; dorsal margin broadly convex; wall smooth, chloroplast with many scattered pyrenoids. Cf. Scott \& Prescott (1961, Pl. 2, Fig. 2), Forster (1969, Pl. 3: 1), Lind (1971, Pl. 1, Fig. 12), Islam \& Haroon (1980, Pl. 1, Fig. 9) and Croasdale \& Flint (1986, Pl. 6, Figs 11: 12).

Closterium gracile Brebisson (1839)

L. 267-380; W. 7-13. Pl. 1:19, 20; Fig. 2: 1-4

Cells very slender, straight and cylindrical with parallel margins gracefully incurved and slightly tapered towards obtuse apices which are rounded-truncate; walls smooth and colourless; chloroplast with 7-9 pyrenoids. Cf. Scott \& Prescott (1961, Pl. 2, Figs 16, 17), Croasdale \& Grönblad (1964, P1. 3, Fig. 12), Forster (1969, Pl. 2: 18, 19) and Croasdale \& Flint (1986, Pl. 8, Figs 3, $4,6)$.

\section{Closterium incurvum Brebisson (1856)}

L. 44-47; W. 8-9. P1. 1: 21

Cells small, very strongly curved, $160-180^{\circ}$ of arc; ventral margin concave, strongly attenuated to narrow, acutely rounded apices. This species is differentiated from $\mathrm{Cl}$. venus Kützing by its smaller size, greater degree of curvature, and sharper apices (Cook, 1963, p. 9, Figs 8, 18). Cf. Forster (1982, P1. 8, Figs 11, 12), Croasdale \& Flint (1986, Pl. 6, Figs 1, 2) and Ling \& Tyler (1986, P1. 5: 20).

\section{Closterium kuetzingii Brebisson (1856)}

\section{386-665; W. 16-19. P1. 2: 6, 7; Fig. 2: 14, 15}

Cells 24-35 times longer than broad, mostly straight, the middle portion fusiform with ventral and dorsal margins almost equally convex, gradually attenuated into long cylindrical processes which are incurved towards the slightly swollen apices. Chloroplast with 5-8 pyrenoids. Cf. Scot \& Prescott (1958, Fig. 1:4), Scott \& Prescott (1961, Pl. 1, Fig. 23), Croasdale \& Grönblad (1964, P1. 4, Figs 11, 12), Scott et al. (1965, Figs 21, 22), Lind (1967, Pl. 1, Figs 6, 7), Forster (1969, Pl. 4: 7-11), Islam \& Haroon (1980, Pl. 1, Fig. 16), Croasdale \& Flint (1986, Pl. 11, Figs 6, 7), Ling \& Tyler (1986, Pl. 7:1) and Gerrath \& John (1988, P1. 9, Figs 5-7).

**Closterium kuetzingii Brebisson var. kuetzingii $\mathrm{f}$. croasdaleae. Forster (1969)

L. 400-460; W. 12-15. Pl. 2: 8; Fig. 2: 21

Cells only slightly swollen in the mid-region; evenly tapered to narrow incurved apices; chloroplast with 7-9 pyrenoids in each semi-cell. This plant is synonymous with $\mathrm{Cl}$. kuetzingii Brebisson, forma described by Scott et al. (1965, Pl. 1: 22). Cf. also Forster (1969), Pl. 4: 12; 1982, P1. 12, Fig. 8).
Closterium lanceolatum (Kützing.) in Ralfs (1848)

L. 486-510; W. 70-75. P1. 3: 8; Fig. 4: 8

Cells broad, fusiform and straight, about 7 times longer than broad; ventral and dorsal margins almost equally convex, and gradually and smoothly attenuated from the mid-region towards truncately rounded obtuse apices; wall smooth, pyrenoids scattered. Cf. Grönblad \& Croasdale (1971, Fig. 6) and Croasdale \& Flint (1986, P1. 9, Figs 1, 2).

*Closterium leibleinii Kützing (1847)

L. 263-286; W. 53-57. Fig. 3: 12, 13

Cells strongly curved. $155-170^{\circ}$ of arc; ventral margin concave, slightly tumid in the mid-region, tapering toward narrow acutely rounded apices; cell wall smooth. Cf. Islam \& Haroon (1980, Pl. 1, Figs 6, 7). Croasdale \& Flint (1986, Pl. 6, Figs 9, 10) and Gerrath \& John (1988, Pl. 3, Figs 10, 11).

Closterium libellula Focke var. interruptum (W. West \& G.S. West) Donat (1926)

L. 139-145; W. 23-25. Pl. 1: 17; Fig. 4: 10

Cells stout, relatively short and straight, 5-6 times longer than broad, apices broad, truncate and rounded; chloroplast plates interrupted at about the middle of each semi-cell. One of the very few straight Closteria; wall smooth, 4-5 pyrenoids in each semi-cell. Cf. Krieger (1932-33, Pl. V, Fig. 4), Scott \& Prescott (1958, Fig. 1: 6), Scott et al. (1965, Fig. 10), Forster (1969, Pl. 2: 15) and Lind \& Tyler (1986, P1. 5: 4, 5). Some authors also refer to this plant as Closterium closteroides (Ralfs) Louis \& Peeters (see Forster (1982, P1. 3, Figs 11-13) and Croasdale \& Flint (1986, Pl. 4, Figs 7, 8).

Closterium lineatum Ehrenberg ex Ralfs(1848)

L. 296-674; W. 14-20, Pl. 1: 23; Fig. 2: 5-9

Cells long and linearly narrow, 21-40 times longer than broad; median portion straight and cylindrical, gradually tapered to incurved obliquely truncate apices; walls striate, reddish-brown in colour. Cf. Scott \& Prescott (1961, Pl. 1, Fig. 26), Croasdale \& Grönblad (1964, Pl. 4, Fig. 10), Lind (1971, Pl. 1, Fig. 15), Forster (1982, Pl. 5, Fig. 9), Croasdale \& Flint (1986, Pl. 11, Figs 1-4) and Gerrath \& John (1988, Pl. 9, Fig. 3).

Closterium lineatum (Ehrenberg) Ralfs var. curvatum Thomasson (1966)

L. 420-438; W. 13-1. Pl. 2: 3

Cells slender, narrow and curved with about $85-90^{\circ}$ of arc; this variety differs from the normal species in its curved shape. Other features, such as size and the subparallel sides of the cells are those of $\mathrm{Cl}$. lineatum (Ehr.) Ralfs. Thomasson (1966, Pl. IV, Fig. 5) described a similar plant from samples collected from Lake Shiwa Ngandu.

Closterium lunula (Müller) Nitzsch. ex Ralfs (1848) L. 554-620; W. 96-106. Pl. 3: 5

Cells large and stout, 6-7 times longer than broad, almost straight, moderately curved, $40-60^{\circ}$ of arc; ventral margin slightly convex in the median part and gradually 
narrowed to conical, bluntly, rounded, slightly recurved apices; chloroplast with 8-10 ridges; pyrenoids many and scattered; cell wall smooth and colourless. Cf. van Oye (1953, Fig. 9), Scott, Grönblad \& Croasdale (1965, Fig. 19) and Croasdale \& Flint (1986, Pl. 7, Figs 8-10).

*Closterium lunula (Müller) Nitzsch var. maximum Borge (1906)

L. 500-625; W. 111-126. Pl. 3: 6; Fig. 3: 3

Cells very large, 4-5 times longer than broad, ventral margin strongly tumid in the mid-region, thereafter gradually attenuated to conical, bluntly rounded apices; moderately curved, $65-105^{\circ}$ of arc; chloroplast with many ridges, pyrenoids scattered. Cf. Grönblad \& Croasdale (1971, Fig. 9).

*Closterium lunula (Müller) Nitzsch var. maximum Borge f. crassissimum Croasdale (1971)

L. 634; W. $197 . \quad$ P1. 3: 7; Fig. 3: 2

Cells large, of exceptionally great breadth, 3.2 times longer than broad; ventral margin strongly swollen in the mid-region before tapering to broad widely truncate rounded apices. This specimen, the only one found is larger than that reported by Grönblad \& Croasdale (1971, Fig. 10) from Namibia.

Closterium monoliferum (Bory) Ehrenberg ex Ralfs (1848)

$\begin{array}{ll}\text { L. 480-720; W. 64-93. Pl. 3: 11; Fig. 3: } 6 & 0\end{array}$

Cells generally large and strongly curved, $105-150^{\circ}$ of arc; ventral margin slightly swollen in the median portion, and strongly attenuated to truncate acute rounded apices; cell wall smooth; 7-12 pyrenoids in the central chloroplast ridge; in some forms pyrenoids are many and scattered. Cf. Bourrelly (1957, Fig. 15), Croasdale \& Grönblad (1964, Pl. 3, Fig. 1), Forster (1969, Pl. 2: 30), Islam \& Haroon (1985, Pl. 1, Figs 7-10), Gerrath \& John (1988, Pl. 4, Figs 2, 3).

*Closterium porrectum Nordstedt var. borgei (Borge) Forster (1964)

L. 450-566; W. 56-66. Fig. 3: 5

A large plant characterised by its lesser degree of curvature $\left(130-145^{\circ}\right)$ and relatively wide tumid diameter than is presented by the typical species. Cf. Forster (1964, Fig. 1: 15), Scott et al. (1965, Fig. 16), Thomasson (1971, Fig. 8: 10, 11). Similar plants were also reported by Borge (1903, Fig. 1: 20).

Closterium pronum Brebisson (1856)

L. 300-360; W. 9-12. Pl. 1: 22

Cells bigger than most reported species; almost straight, ventral margin slightly tumid in the mid-region and curved at the apices; sometimes sigmoid; 40-45 times longer than broad; cell wall smooth and colourless. Cf. Scott \& Prescott (1958, Pl. 2, Fig. 42), Ling \& Tyler (1986, P1. 8: 1, 2).

**Closterium pseudolunula Borge var. concavum Forster \& Eckert (1963)

$\begin{array}{ll}\text { L. 340-390; W. 37-50. } & \text { Pl. 3: 4; Fig. 3: } 7\end{array}$
Cells almost straight, $30-40^{\circ}$ of arc; ventral margin virtually straight, gradually narrowed into wide blunt obtusely rounded apices; chloroplast with 5-9 pyrenoids. Cf. Forster (1963, Pl. 1:8), Forster (1969, Pl. 4: 16-18) and Islam \& Haroon (1980, Pl. 1, Fig. 13).

Closterium ralfsii Brebisson (1844)

L. 420-596; W. 36-38. Fig. 2: 12, 16

Cells from 12-16 times longer than broad, slightly curved, $35-50^{\circ}$ of arc; ventral margin more inflated than the dorsal, strongly attenuated to narrow slightly incurved apices; cell wall finely striate and reddish-brown. Cf. Croasdale \& Grönblad (1964, Pl. 4, Fig. 7) and Croasdale \& Flint (1986, Pl. 10, Fig. 8).

Closterium ralfsii Breb. var. hybridum Rabenhorst (1863)

L. 480-504; W. 30-33. Pl. 2: 9; Fig. 2: 13

A variety more slender than most reported forms, 15-17 times longer than broad; cells nearly straight, $35-45^{\circ}$ of arc; ventral margin slightly tumid in the mid-region and strongly tapered towards acutely truncate apices; walls finely striate, yellowish-brown in colour. Cf. Scott \& Prescott (1958, Fig. 1: 13), Scott \& Prescott (1961, Pl. 1, Fig. 25), Croasdale \& Grönblad (1964, Pl. 4, Fig. 8), Forster (1982, P1. 11, Fig. 2), Croasdale \& Flint (1986, Pl. 10, Figs 10, 11), Ling \& Tyler (1986, P1. 7:2) and Gerrath \& John (1988, Pl. 7, Fig. 5).

\section{**Closterium rectimarginatum Scott \& Prescott (1961) $\begin{array}{ll}\text { L. 280-301; W. 33-46. P1. 1: } 18 & \text { P }\end{array}$ \\ Cells flat and spindle shaped, of medium size, about 6-9 times longer than broad; lateral margins almost perfec- tly straight from the mid-region to the narrowly rounded apices; cell wall smooth and reddish-brown; chloroplast with 5-7 pyrenoids. The present plants which do not ap- pear to have been reported for Africa are much larger than the original species described by Scott \& Prescott (1961, Pl. 1, Figs 27, 28) from Indonesia and also the specimen reported by Ling \& Tyler (1986, Pl. 5: 31) from Australia.}

Closterium rostratum Ehrenberg (1828)

$\begin{array}{ll}\text { L. 400-428; W. 43-47. P1. 3: 3; Fig. 4: } 7 & \text {. }\end{array}$

Cells large, about 9 times longer than broad; slightly curved, $35-45^{\circ}$ of arc; ventral margin strongly tumid in the mid-region and more convex than the dorsal margin; strongly attenuated to produce narrow, slender extremities with parallel sides, terminated by incurved obliquely rounded apices; wall smooth and striate in the mid-region. Cf. Grönblad et al. (1968, Fig. 21), Agarker \& Agarker (1977, Fig. 3), Forster (1982, P1. 12, Fig. 1) and Croasdale \& Flint (1986, P1. 11, Figs 11-14).

**Closterium rostratum Ehrenberg var. brevirostratum W. West (1904)

L. 280-286; W. 46-50. Pl. 1: 15, 16; Fig. 4: 9

Cells shorter than the normally reported species; about 6 times longer than broad; ventral margin strongly tumid and attenuated to produce short slender extremities. Cf. 
Thomasson (1967, Fig. 4: 6), Ruzicka (1977, Pl. 31: 7) and Forster (1982, Pl. 12, Fig. 2).

Closterium setaceum Ehrenberg ex Ralfs (1848)

L. 357-420; W. 13-17. P1. 2: 4, 5; Fig. 2: 18

Cells slender, median portion fusiform; 25-27 times longer than broad, tapers abruptly into long slender and cylindrical processes longer than the swollen median portion and nearly straight except at their incurved obtuse apices; chloroplast with 2-3 pyrenoids restricted to the mid-region; cell wall striate and pale yellow or colourless. Cf. Scott \& Prescott (1961, Pl. 1, Fig. 21), Lind (1967, Pl. 1, Figs 10, 11), Grönblad et al. (1968, Fig. 19), Forster (1969, Pl. 4: 13-15), Lind (1971, Pl. 1, Fig. 17), Croasdale \& Flint (1986, Pl. 11, Figs 15, 16), Gerrath \& John (1988, P1. 9, Fig. 4).

*Closterium spetsbergense Borge var. laticeps Grönblad f. maius Grönblad. (1921)

L. 760; W. 80 . Fig. 3: 1

Cells stout and very large, about 9.5 times longer than broad; almost straight, $40^{\circ}$ of arc; ventral margin virtually straight; tapered at the poles into broadly truncate rounded apices. This plant in all respects, appears identical with that reported by Grönblad \& Croasdale (1971, Fig. 11) from Namibia. It is much larger than the variety described by Grönblad (1921, P1. 5:43) as Cl. spetsbergense var. laticeps. Krieger (1937, p. 305) puts this species under $\mathrm{Cl}$. pseudolunula Borge, but this does not seem appropriate on account of the fact that Borge (1911, Fig. 5) had given the name $\mathrm{Cl}$. spetsbergense to the species and his original figures show them to be very different.

Closterium strigosum Brebisson (1856)

L. 227-234; W. 19-23, Fig. 2: 19

Cells 11-12 times longer than broad; slightly bent, 20$30^{\circ}$ of arc; ventral margin straight or very slightly tumid; poles slightly incurved with narrow subacute apices. Cf. Ruzicka (1977, Pl. 22: 5), Compere (1977) from Lake Chad and Croasdale \& Flint (1986, Pl. 8, Figs 1, 2).

Closterium striolatum Ehrenberg in Ralfs (1848)

L. 290-354; W. 29-36, Pl. 2: 12

Cells moderately large, about 10 times longer than broad; a little curved, $35-80^{\circ}$ of arc; the median portion of ventral origin sometimes straight, or else slightly swollen, gradually attenuated to broadly rounded truncate apices sometimes slightly capitate with thickened wall; cell wall striate and brownish. Cf. Van Oye (1953, Fig. 19), Scott \& Prescott (1958, Fig. 1:11), Scott \& Prescott (1961, P1. 2, Fig. 22), Croasdale \& Grönblad (1964, Pl. 4, Figs 5, 6), Islam \& Haroon (1980, P1. 2, Fig. 25), Forster (1982, Pl. 6, Figs 11, 12), Croasdale \& Flint (1986, Pl. 10, Figs 1, 2) and Ling \& Tyler (1986, Pl. 7: 6-8).

**Closterium subulatum (Kützing) Brebisson var. maius Krieger (1937)

L. 320; W. 20;

Fig. 2: 17
Cells 16-18 times longer than broad; almost straight, 20$30^{\circ}$ of arc; middle portion tumid and fusiform; ventral margin more convex and attenuated into slender slightly incurved apices. Cf. Krieger (1937, Pl. 13:9), Croasdale \& Grönblad (1964, Pl. 2, Fig. 9) and Forster (1969, Pl. 4: 6).

Closterium turgidum Ehrenberg var. borgei (Borge) Deflandre (1924)

L. 703-1391; W. 47-89. Pl. 3: 2; Fig. 4: 4, 5

Cells very large, 15-17 times longer than broad; slightly curved, $38-45^{\circ}$ of arc; ventral margin slightly concave; the variety is distinguished from the typical species by the proportional increase in length and breadth and the appearance of the extremities which are obtuse and somewhat angular; cell wall yellowish-brown, finely striate with about 10-12 striae in $10 \mu \mathrm{m}$; chloroplasts with ridges and scattered pyrenoids. Plants widely distributed and cosmopolitan. Cf. Van Oye (1953, Fig. 22), Scott \& Prescott (1961, Pl. 1, Fig. 24), Grönblad \& Croasdale (1964, Fig. 4), Lind (1967, Pl. 1, Figs 13, 16) Lind (1971, Pl. 1, Fig. 18), Grönblad \& Croasdale (1971, Fig. 12), Islam \& Haroon (1980, Pl. 2, Fig. 22) and Forster (1982, Pl. 8, Figs 7-9).

\section{Genus PLEUROTAENIUM Naegeli 1849}

Pleurotaenium baculoides (Roy \& Bisset) Playfair (1907)

L. 562-846; W. 35-38 Pl. 4: 14; Fig. 5: 14, 15

Cells of varying length, 10-17 times longer than broad; semi-cell with one prominent basal inflation, broad in the middle and tapering towards a truncate apex; cell wall smooth. Cf. Scott \& Prescott (1961, Fig. 5), Grönblad et al. (1964, Fig. 7), Lind (1971, Pl. 1, Fig. 1) and Forster (1982, Pl. 13, Fig. 8).

Pleurotaenium coronatum (Brebisson) Rabenhorst (1868)

L. 480-512; W. 42-45; Wa. 30-32; Pl. 4: 6; Fig. 6: 6

Cells narrow, about 12 times longer than broad; diameter of semi-cells much reduced above the basal swellings, and widest in the mid-region, tapering to a rounded apex. Cf. Forster (1969, Pl. 6: 12, 13); Forster (1982, Pl. 14, Fig. 6) and Ling \&Tyler (1986, Pl. 12: 8).

Pleurotaenium coronatum (Brebisson) Rabenhorst var. coronatum Croasdale (1965)

L. 518-524; W. 40-43; Wa. 26-28 Pl. 4: 7

Semicells somewhat flexuous and slightly tapered to the rounded apices; distinct basal swelling with 2-3 undulations after it; wall apparently smooth. Cf. Scott, Grönblad \& Croasdale (1965, Fig. 35)

Pleurotaenium coronatum (Brebisson) Rabenhorst var. fluctuatum W. West (1892)

L. 293-340; W. 22-24; Pl. 4: 4; Fig. 6: 7

Cells generally slender, shorter than the normal, about 16 times longer than broad, margins undulate throughout the lenght of the cell, with at least 12 undu- 
lations per semi-cell; semi-cell dilated at the apex and terminated by a ring of teeth or tubercles. Cf. Lind (1971, Pl. 1, Fig. 2) and Forster (1982, Pl. 14, Fig. 7). This appears to be the same plant described by Scott \& Prescott (1958, Fig. 2: 9, 10) and Ling \& Tyler (1986, Pl. 12: 17) as Pl. burmense (Joshua) Krieger (1937) var. curtum Scott \& Prescott. See also Thomasson (1971, Figs 4: 5, 6; 5: 3, 7; 7: 13-15).

**Pleurotaenium coronatum (Brebisson) Rabenhorst var. nodulosum (Brebisson) W. West \& G.S. West f. constrictum Krieger (1937)

\section{580-670; W. 42-46; Pl. 4: 5; Fig. 5: 12}

Cells narrow and long, 16-17 times longer than broad; semi-cells have narrowest diameter above the isthmus and taper gradually towards the poles; apex flattened with a ring of tubercles. Cf. Krieger (1937, P1. 49, Fig. 1) and Scott \& Prescott (1958, Fig. 2:6).

*Pleurotaenium ehrenbergii (Brebisson) De Bary (1858)

$\begin{array}{ll}\text { L. 420-450; W. 33-36 Pl. 4: } 8 & \end{array}$

Plants stout and cylindrical, about 17 times longer than broad; semi-cells with widest diameters at the base above the isthmus, tapering gradually towards the poles; apex with faint terminal tubercules. Cf. West \& West (1904, P1. 29, Figs 9-11), Scott \& Prescott (1958, Fig. 2: 2), Lind (1971, Pl. 1, Fig. 4), Prescott et al. (1975, Pl. 45: 1-5), Ling \& Tyler (1986, Pl. 13: 15, 16) and Gerrath \& John (1988, Pl. 10, Fig. 7).

\section{*Pleurotaenium maculatum (Turner) Krieger (1939)}

\section{756-767; W. 53-56 Fig. 5: 8, 9}

Cells large and robust, very long, about 16 times longer than broad, semi-cells of even diameter, with one distinct basal swelling above the isthmus and terminating in an expanded apex ornamented by a ring of 13-16 prominent conical tubercules. Lind (1971, P1. 10, Figs 1, 1a) described a similar plant from the desmids collected in Uganda. On the other hand, the plant described by Bourrelly (1957, Pl. 1, Fig. 8) from the district of Macina, West Africa, is a much shorter form.

**Pleurotaenium minutum (Ralfs) Delponte var. latum Kaiser (1931)

L. 260-320; W. 21-23; Wa. 15-16. Pl. 4: 12

Cells of this variety generally, as a rule, lack basal inflations but are angularly tapered at the apex; cells stout, 12-13 times longer than broad and considerably larger than the taxon described by Kaiser (1931). It resembles some form of $\mathrm{Pl}$. trabecula (Ehrenberg) Naegeli except that there is no trace of basal swellings. Cf. Scott \& Prescott (1961, Pl. 121-122) and Ling \& Tyler (1986, Pl. 13: 14).

\section{Pleurotaenium ovatum Nordstedt (1877)}

L. 370-410; W. 86-93; I. 70-74; Pl. 4: 15; Fig. 6: 1 Cells large and robust, about 4 times longer than broad; semi-cells without a basal swelling, gradually dilated to about one quarter of the length of the cell, then tapering evenly towards the apices; apex flat and broad bearing a ring of tubercules, 5-7 of them visible in face view; chloroplast parietal with ribbon-like ridges, each with numerous pyrenoids. Cf. Scott \& Prescott (1961, Pl. 6, Figs 1, 2), Thomasson (1965, Fig. 5: 5), Lind (1971, Pl. 1, Fig. 5), Hirano (1972, Pl. 1, Fig. 7), Islam \& Haroon (1980, Pl. 4, Fig. 63). The desmid Pleurotaenium ovatum Nordstedt belongs to large group of desmids whose distribution had hitherto been said to be limited to the tropical and sub-tropical regions of Africa, Asia, Australia and South America. Recently, Croasdale \& Flint (1986, Pl. 13, Figs 3-8) reported the presence of the plants in New Zealand.

*Pleurotaenium ovatum Nordstedt var. elephantinum (Cohn) Krieger (1937)

L. 596-660; W. 109-112; I. 81-83; Pl. 5: 4; Fig. 6: 3

Cells longer than the typical species, about 4 times longer than broad. The plant reported by Krieger (1937) had smooth apices while Cohn (1879) had drawings with small apical teeth. The Tanzanian desmids reported by Lind (1967, P1. 2, Figs 1, 2 \& Photo 1) had small, rounded apical tubercules of which 7-8 were visible in front view. The present plants are similar to Krieger's in having smooth apices.

**Pleurotaenium ovatum Nordstedt. var. inermius Mobius (1894)

L. 256-310; W. 77-89; I. 48-52; Pl. 5: 3; Fig. 6: 5

Cells shorter and broader than the typical species; resemble variety tumidum but with smooth ends; 3 times longer than broad. Cf. Mobius (1894, Pl. 2: 18-19), Krieger (1937, P1. 50: 5), Scott \& Prescott (1961, P1. 6, Figs 3, 4), Islam \& Haroon (1980, P1. 24, Fig. 375) and Ling \& Tyler (1986, Pl. 13: 11). This is the first report of this taxon for Africa.

*Pleurotaenium ovatum Nordstedt var. tumidum (Maskell) G.S. West (1907)

L. 254-420; W. 86-126; I. 76-82; Pl. 5: 1,2; Fig. 6: 2, 4

Cells relatively short, thicker and broad, 3 times longer than broad; semi-cell with an abrupt swelling above the isthmus and tapering in a smooth curve to a truncate apex ornamented with conspicuous tubercules or teeth. Cf. Hardy (1906, Pl. 21), Krieger (1937, Pl. 50: 2, 3), Grönblad \& Croasdale (1971, Fig. 13), Croasdale \& Flint (1986, Pl. 13, Figs 5-8) and Ling \& Tyler (1986, P1. 13: 10).

*Pleurotaenium simplissimum Grönblad var. simplissimum Krieger (1937)

L. 864; W. 42; $\quad$ Pl. 4: 13; Fig. 5: 7

Cells very long and narrow, about 20 times longer than broad; semi-cell with narrowest diameter a little below the apex; apex a little dilated with 12-14 tubercules; cell wall with no visible undulations.

Pleurotaenium subcoronulatum (Turner) W. West \& G. S. West (1895)

L. 366; W. 36; Pl. 4: 1; Fig. 5: 13

Cells narrow and long, forming chains of short filaments, usually of up to 4 cells in length; semi-cell with 
one distinct basal swelling, followed by a series of undulations; attenuated towards the poles; apex expanded and crowned with a ring of between 10 and 12 distinct conical tubercules. Dichotypic forms in which the semicells are markedly different in length are not uncommon, the illustrations here (Pl. 4:1 \& Fig. 5:13) being some examples. Cf. Turner (1892, Pl. 3: 1), W. West \& G.S. West (1895, Pl. 5: 13), Scott \& Prescott (1961, Pl. 4, Figs 1, 2), Lind (1967, Pl. 1, Fig. 21), Prescott et al. (1975, Pl. 49: 2-5) and Ling \& Tyler (1986, Pl. 12: 12, 19-24).

*Pleurotaenium subcoronulatum (Turner) West \& G. S. West var. africanum Schmidle (1902)

\section{$\begin{array}{ll}\text { L. 350-530; W. 28-32 Pl. 4: 2, 3; Fig. 5: } 6 & \end{array}$}

Cells narrow and long and of different lengths, most of them forming chains of varying number of cells; semicell with a distinct basal inflation, above which there are no visible undulations as is characteristic of reported forms; apex dilated and terminated by a ring of tubercles; 2-4 ribbon-like chloroplasts in each semi-cell. Cf. Grönblad et al. (1958, Pl. 11), Lind (1971, p. 539) and van Oye (1953, Figs 29, 30).

**Pleurotaenium subcoronulatum (Turner) W. West \& G.S. West var. spinulosum Opute var. nova

\section{480-512; W. 47-52; Fig. 5: 11.}

Cells about ten times longer than broad; occurs singly or in short chains of 2-4 cells in a filament; semi-cell with one distinct basal inflation and no further undulations; apex expanded and crowned with characteristic conical tubercles, 12-14 in number; cell wall covered with a tuft of fine hairs or spines. In consideration of the prominent tubercles and the filamentous habit, this taxon approximates to the species subcoronulatum, but differs from any reported form in the possession of copious stout spines covering the entire cell surface. A new variety is therefore suggested.

DIAGNOSIS: Haec varietas proxime et similis ad Pleurotaenium subcoronulatum, sed differt ab illum cum membrana spinis multo possidero. Long. 480-512 $\mu \mathrm{m}$, lat. 47-52 $\mu \mathrm{m}$, lat. cum spin, 52-56 $\mu \mathrm{m}$.

Pleurotaenium trabecula (Ehrenberg) Naegeli (1849)

\section{460-498; W. 24-28; Pl. 4: 9; Fig. 5: 16}

Cells 15-18 times longer than broad; semi-cells widest in the mid-region, then tapering to truncate rounded apex without ornaments; each semi-cell has a distinct basal inflation with 1-3 slight undulations beyond; cell wall smooth, chloroplasts parietal with longitudinal bands containing numerous pyrenoids. Cf. Scott \& Prescott (1958, Fig. 2: 4), Scott \& Prescott (1961, Pl. 3, Fig. 4), Forster (1969, Pl. 6: 3); 1982, Pl. 13, Figs 1113), Islam \& Haroon (1980, Pl. 4, Fig. 58), Islam \& Haroon (1985, Pl. 1, Fig. 18) and Gerrath \& John (1988, P1. 10, Fig. 4).

*Pleurotaenium trabecula (Ehrenberg) Naegeli var. crassum Ruzicka (1977)

L. 480-590; W. 44-48; Pl. 4: 11.
Cell relatively large and broad; 10-12 times longer than broad; semi-cell with a slight basal inflation and 1-2 hardly discernible undulations beyond; a little swollen in the mid-region, then tapering to a rounded truncate apex devoid of tubercles; chloroplast parietal with longitudinal bands each with 5-7 pyrenoids. Cf. Ruzicka (1977, P1. 38: 6, 7).

*Pleurotaenium trabecula (Ehrenberg) Naegeli var. rectum (Delponte) W. West \& G. S. West. In W. West, G.S. West \& Carter (1904)

\section{420-436; W. 23-26 Pl. 4: 10; Fig. 6: 8}

Cells 14-15 times longer than broad; a variety more slender and of nearly uniform width; slightly tapering at the apices; each semi-cell has a single basal inflation, smooth cell wall and a truncated rounded smooth apex. Cf. Scott \& Prescott (1958, Fig. 2: 5), Forster (1969, P1. 6: 4-6) and Gerrath \& John (1988, Pl. 10, Fig. 6).

\section{Genus TRIPLOCERAS Bailey (1851)}

*Triploceras gracile Bailey var. bidentum Nordstedt (1888)

L. 475-600; W. 42-56; P1. 6: 9; Fig. 6: 9

Cells about 14 times longer than broad; this is a stout variety with more elaborate ornamentations, arranged in whorls about 12 of them in each semi-cell; each whorl has a circle of acute thickened projections or teeth; semi-cells tapering to a 2-lobed apex, each lobe tipped with 3 spines. Cf. Bourrelly (1957, Pl. 1, Fig. 10), Scott et al. (1965, Fig. 42) and Forster (1969, Pl. 7: 4, 5); 1982, Pl. 16, Figs 4-6).

\section{Genus TETMEMORUS Ralfs (1844)}

Tetmemorus brebissonii (Meneghini) Ralfs (1844)

L. 120-286; W. 24-66 Pl. 3: 12, 13; Fig. 4: 14, 15

Cells cylindrical or fusiform, 5-6 times longer than broad, with a conspicuous median constriction; distinguishable from other similar looking genera by its broad apices with moderately deep median incisions; semi-cell in face view only slightly tapered, in side view strongly tapered; cell wall with rows of punctae or scrobiculations; separated from the closely related Euastrum by its axial chloroplast with a central row of pyrenoids. Cf. Scott \& Prescott (1958, Fig. 20: 11), Forster (1982, Pl. 39, Fig. 10) and Ling \& Tyler (1986, Pl. 5: 15, 16).

\section{Genus SPHAEROZOSMA Corda in Ralfs (1948)}

*Sphaerozosma aubertianum W. West var. compressum Rich (1932)

L. 20-22; W. 33-36; I. 7-8; Pl. 6: 1

Cells large, about 1.5 times broader than long, with deep median constriction; sinus narrow and linear, isthmus narrow; semi-cells compressed and oblong-elliptical; lateral margins rounded and slightly notched with two papillae or granules one on each side of the notch. The present plants are bigger than those described by Rich (1932, Fig. 17-A). Cf. Thomasson (1963, Fig. 34: 1, 2), 
Thomasson (1965, Fig. 4: 5) and Thomasson (1966, Fig. 10: 12).

* Sphaerozosma granulatum Roy \& Bisset (1886)

L. 12-14; W. 8-10; I. 6-7; Pl. 5: 9,10

Cells Cosmarium-type, a little longer than broad; sinus shallow, with well-defined median isthmus; united to form permanent filaments by short apical appendages; lateral margins granulate with symmetrically arranged warts. Cf. Krieger (1932, Pl. 26:4), Grönblad et al. (1958, p. 44), Grönblad (1960, Figs 183, 184), Lind (1967, p. 382) and Forster (1969, Pl. 53, Figs 1-3).

\section{Genus SPONDYLOSUM Brebisson. (1844).}

Spondylosum planum (Wolle) W. \& G. S. West (1912). L. 11-13; W. 10-12; I. 8-10; $\quad$ Fig. 7: 6

Cells slightly longer than broad; in some cases as long as broad, moderately constricted; sinus shallow and open; cells joined together by mucilaginous pads; no appendages on cell apices; semi-cells transversely oblong with broadly rounded angles and flattened apices; cell wall smooth and unornamented. Cf. Scott \& Prescott (1961, Pl. 60, Figs 6-8), Thomasson (1966, Pl. 20, Fig. 2), Lind (1967, Pl. 11, Fig. 8) and Forster (1969, Pl. 52:9, 10).

**Spondylosum pulchrum (Bailey) Archer in Smith (1924).

L. 15-16; W. 21-22; I. 7-8; Fig. 7: 7

Cells compressed and broad, 1.5 times to twice wider than long, median constriction deep; sinus widely open from a rounded apex; semi-cells very broad and transversely oblong-elliptic with rounded angles; apical ends widely truncate with the central portion slightly elevated; cell wall smooth. Cf. Scott et al. (1965, Fig. 236).

\section{Genus ONYCHONEMA Wallich (1860)}

*Onychonema laeve Nordstedt var. latum W. \& G.S. West (1896)

L. 16-18; W. 33-38; I. 4-6 Pl. 6:3,4; Fig. 7: 14

Cells about 2 times broader than long, median constriction deep, with narrow isthmus; sinus narrow and linear before opening out; semi-cells compressed and transversely oblong-elliptic; lateral sides produced into short stout incurved spines; apical ends broadly rounded and convex, equipped with two widely spaced diagonally arranged fusiform inter-locking processes or appendages, terminated in small rounded knobs; cells united into filaments through these appendages. The variety perlatum described by Grönblad et al. (1958, Fig. 327 \& photo 392 ) is characterised by very broad and depressed cells; spines are short, acute and parallel. Cf. Scott \& Prescott (1958, Fig. 21: 2), Scott \& Prescott (1961, Pl. 60, Fig. 13), Forster (1969, Pl. 53: 8-11) and Lind (1971, Pl. 6, Fig. 5).

\section{Genus HYLOTHECA (Ehrenberg) Ralfs (1848)}

Hylotheca dissiliens (Smith) Brebisson in Ralfs (1848) L. 14-17; W. 14-18 Pl. 6: 8; Fig. 7: 4, 5

Cells approximately quadrate, cylindrically discoid and usually broader than long; median constriction hardly discernible and the sinus exists as a slight depression midway between the poles which are flattened with slightly rounded angles; cells united to form long filaments, enveloped in a continuous mucous sheath; cell wall unornamented, chloroplasts axile with a single pyrenoid. Filaments were very common in the plankton. Cf. van Oye (1953, Fig. 81), Lind (1967, p. 381) and Lind (1971, p. 516).

**Hylotheca undulata Nordstedt var. perundulata Grönblad (1938)

L. 18-20; W. 6-6.5;

P1. 6: 7; Fig. 7: 3

Cells narrow, elongate, about 3 times longer than broad, median constriction moderate; sinus broad, shallow and widely open, isthmus relatively broad; semi-cells biundulate, apices truncate. In some cases the undulation of the semi-cells is barely evident. Cf. Grönblad (1938, Pl. 4: 2). Scott \& Prescott (1961, Pl. 61, Fig. 4) and Scott et al (1965, Fig. 243).

Genus PHYMATODOCIS Nordstedt (1877)

*Phymatodocis irregulare Schmidle var. intermedia Gutwinski (1902)

L. 27-29; W.57-60; I. 40-43 Pl. 6: 2; Fig. 7: 16

Cells asymmetrical, united into short filaments, about twice as broad as long; median incision not so deep; sinus narrow and linear; semi-cells of irregular shape; facial view reveals clumps of cell material which Gutwinski (1902, Pl. 36, Fig. 4e) referred to as "zygotes". Scott \& Prescott (1961) explained that the structure referred to by Gutwinski are stages in vegetative division before the formation of the cross-wall. This is the same plant referred to by Scott \& Prescott (1961, Pl. 61, Figs 11$15)$ as Ph. irregularis Schmidle var. intermedia Gutwinski. Cf. also Fritsch \& Rich (1937, Fig. 28-A, B). Bourrelly (1957, Pl. 18, Fig. 157), Forster (1969, Pl. 56:9, 10), Lind (1971, Pl. 6, Figs 9, 10) and Islam \& Haroon (1980, Pl. 12, Fig. 158).

\section{Genus DESMIDIUM Agardh 1824}

*Desmidium aptogonium Breb. var. tetragonum W. \& G. S. West (1902)

L. 18-20; W. 37-38; I. 32-33 Fig. 7: 9.

Cells filamentous, nearly twice as broad as long, median constriction shallow; sinus with a rounded apex and flared sides and a broad isthmus; semi-cell apices broad with a deep, wide semi-elliptical to sub-rectangular depression forming an open space between two adjacent cells. The filaments when long show a twist, about one turn every 15-22 cells. Twisting is not usually apparent in lengths shorter than 5 or 6 cells, which are frequently seen. Cf. Scott \& Prescott (1958, Fig. 21: 4), Scott \& Prescott (1961, Pl. 62, Figs 5-7) and Lind (1971, P1. 6, Fig. 2). 
Desmidium baileyi (Ralfs) Nordstedt. f. tetragonum Nordstedt (1888)

L. 19-20; W. 22-23;

Pl. 5: 8; Fig. 7: 12

Cells a little broader than long, united to form long untwisted filaments; faintly constricted producing a hardly discernable sinus; semi-cells tapered towards the apices; apex with a deep broad sub-rectangular depression yielding an open space between adjoining cells like in $D$. aptogonium; lateral margin with two slight undulations. Cf. Bourrelly (1957, Pl. 15, Fig. 137; Pl. 17, Figs 154, 155), Scott \& Prescott (1958, Fig. 21: 6), Scott \& Prescott (1961, Pl. 62, Figs 8, 9), Scott et al. (1965, Fig. 247), Thomasson (1966, Pl. 20, Fig. 10) and Forster (1969, P1. 56: 12).

*Desmidium coarctatum Nordstedt var. cambricum W. West (1890)

L. 22; W. 25; I. 19 P1. 5, 6; Fig. 7: 13

Cells sub-spherical, broader than long, slightly constricted; sinus a little open notch, isthmus very broad; semi-cells wide at the base, tapering strongly towards the apices; chromatophores axile, one in each semi-cell. Cf. Fritsch \& Rich (1937, Fig. 29-C), van Oye (1953, Fig. 85), Scott \& Grönblad (1957, P1. 36, Figs 4, 5), Scott \& Prescott (1958, Fig. 21: 10, 11) and Lind (1971, P1. 6, Fig. 6).

**Desmidium grevillei (Kützing) De Bary (1858)

L. 24-25; W. 24-26; 19-20 Fig. 7: 15

Cells filamentous, about as long as broad, median constriction shallow; semi-cell with a rounded lateral lobe that tapers abruptly towards the poles; apical margin truncate with diameter about half the size of maximum cell diameter; chloroplasts 4-6 lobes, each lobe with a pyrenoid. Colony filamentous with a mucilage sheath, 5-6 short cells regularly alternating with every 3 large cells. Cf. Scott \& Prescott (1961, Pl. 62, Figs 15, 16), Scott et al (1965, Figs 250, 251), Forster (1969, Pl. 55: $7,8)$ and Islam \& Haroon (1980, Pl. 5, Fig. 76).

*Desmidium quadratum Nordstedt (1873)
L. 15-17; W. 28-29
Pl. 5: 5; Fig. 7: 8

Cells quadrangular and filamentous, a little over 1.5 times broader than long, very faintly constricted; apices of semi-cells flat to slightly curved; two adjoining cells joined by a pad of mucilage, cell wall smooth. Cf. Scott \& Prescott (1961, Pl. 63, Figs 5, 6) and Forster (1969, P1. 54:15).

*Desmidium swartzii Agardh (1824)

\section{17-18; W. 31-33; I. 27 P1. 5: 7; Fig. 7: 10, 11.}

Cells 2 or more times broader than long; median constriction shallow with broad isthmus; semi-cells broadly trapezoidal with lateral margins acutely upturned in the median portion; vertical view triangular; cell wall smooth; cells united as permanent spirally twisted filaments ( 1 turn every 10-20 cells); enclosed in a gelatinous sheath. Cf. Scott \& Grönblad (1957, Pl. 37, Fig. 4), Scott \& Prescott (1958, Fig. 21: 13), Scott \& Prescot (1961, Pl. 63, Fig. 8), Lind (1971, P1. 6, Fig. 4) and Islam \& Haroon (1980, Pl. 16, Figs 224, 225).
Genus BAMBUSINA Kützing 1845

*Bambusina brebissonii Kützing. (1845)

L. 30-32; W. 17-18; Pl. 6: 5

Cells barrel-shaped, united in long permanent filaments, cells twice as long as broad with a slightly median constriction; sinus, a small depression, isthmus very broad; lateral margins of semi-cells with a distinct acute basal bulge and concave sides tapered and converging to a truncate apex; cell apices without protuberances; chloroplasts plate-like. Cf. Scott \& Prescott (1961, P1. 62, Fig. 1), Scott et al. (1965, Fig. 256), Forster (1969, Pl. 53, Figs 19-21), Lind (1971, Pl. 6, Fig. 1) and Islam \& Haroon (1980, P1. 5, Fig. 75).

*Bambusina borreri (Ralfs) Delponte var. grassiliscens (Nordstedt) Wolle (1892)
L. 31-33; W. 18-20
Pl. 6: 6; Fig. 7: 2

Plants similar to $B$. brebissonii (Ralfs) Delp. in being barrel-shaped, united in long permanent filamentous chains except that individual cells appear narrower and are about 1.5 times longer than broad. Cf. Thomasson (1966, Pl. xx, Figs 8, 9) from specimens from Lake Shiwa Ngandu.

Genus COSMOCLADIUM Brebisson 1844

**Cosmocladium pulsillum Hilse in Forster (1982)

L. 14-15; W. 10-11 Pl. 6: 10

Cells Cosmarium-like with deep median constriction; semi-cells elliptical; cells united into irregular colonies by bands of gelatinous material extruded from special pores in the cell wall; chloroplast axile, one in each cell. Cf. Forster (1982, Pl. 18, Figs 7, 8).

\section{ACKNOWLEDGMENTS}

This piece of work was aided partly through a Senate grant from the University of Benin, which made the collection of samples possible. Detailed studies involving access to useful literature and facilities for the bulk of the photomicrographs were made possible through a fellowship under the auspices of the Third World Academy of Sciences, Trieste, in collaboration with the Italian Government.

Over 75 per cent of this study were carried out at the Istituto Italiano di Idrobiologia, Pallanza, Verbania in Italy. I am most grateful to the Director, Dr. Riccardo de Bernardi for making it possible for me to work in the Institute. My special thanks go to Dr. Delio Ruggiu, Dr. Piero Guilizzoni, Dr. Annamaria Nocentini, Dr. Gianluigi Giussani, Dr. Cristiana Callieri, Dr. Rosario Mosello, Dr. Ulderico Melchiorri-Santolini and Mrs Pierisa Panzani for their wonderful kindness, hospitality and for making my sojourn in Pallanza a memorable one.

Professor Doc. Kuno Thomasson, a renowned desmidologist from Vaxbiologiska Institutionem, Uppsala, was very kind in helping with the identification of a number of the taxa. Dr. P.A. Tyler, of the Department of Botany, University of Tasmania, also helped with some identification. I hereby acknowledge their invaluable assistance. Finally I thank the University of Benin for granting me study leave. 

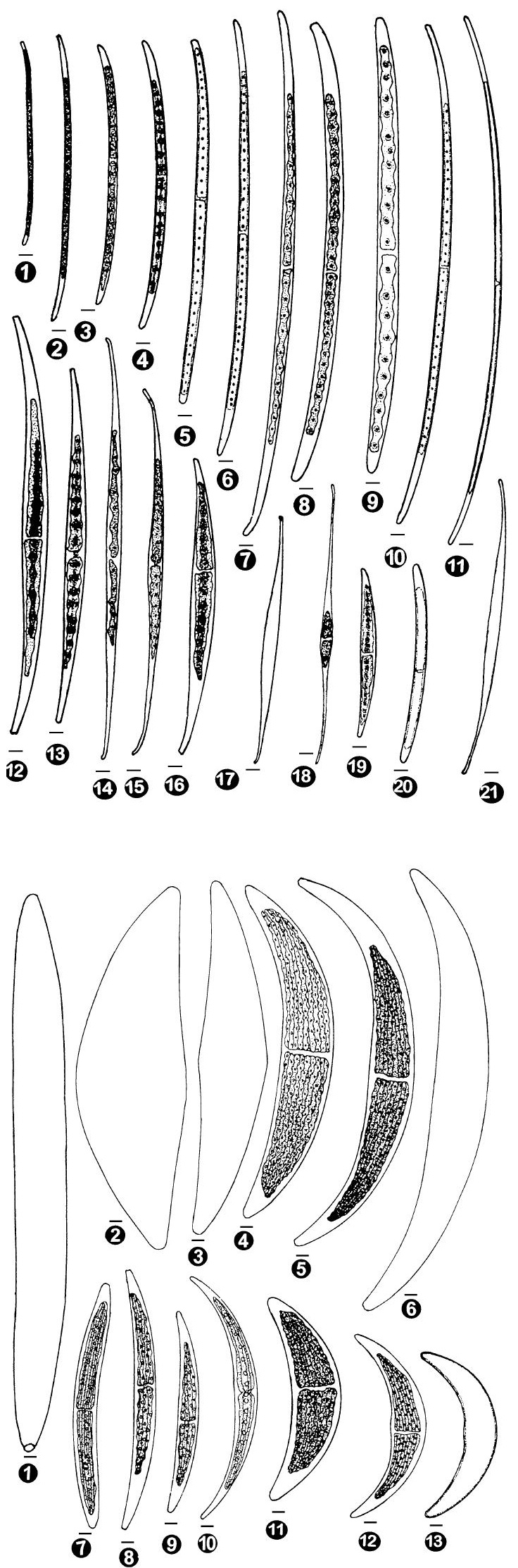

Fig. 2.

1-4. Closterium gracile Breb.

5-9. Closterium lineatum Ehr.

10, 11. Closterium aciculare T. West

12. Closterium ralfsii Breb.

13. Closterium ralfsii Breb. var. hybridum Rabenh.

14, 15. Closterium kuetzingii Breb.

16. Closterium ralfsii Breb.

17. Closterium subulatum (Kütz.) Breb.var. maius Krieger

18. Closterium setaceum Ehr. in Ralfs.

19. Closterium strigosum Breb.

20. Closterium baillyanum Breb. in Ralfs.

21. Closterium kuetzingii Breb. var. kuetzingii f. croasdaleae Forster

Fig. 3.

1. Closterium spetsbergense Borge var. laticeps Gronbl. f. maius Gronbl.

2. Closterium lunula (Müll.) Nitsch. var. maximum Borge f. crassissimum Croasd.

3. Closterium lunula (Müll.) Nitsch. var. maximum Borge

4. Closterium ehrenbergii Menegh. Ex. Ralfs

5. Closterium porrectum Nordst. var. borgei (Borge) Forster

6. Closterium monoliferum (Bory) Ehr. ex. Ralfs

7. Closterium pseudolunula Borge var. concavum Forster \& Eckert

8, 9. Closterium acerosum (Schr.) Ehr.

10. Closterium dianae Ehr. var. arcuatum (Breb.) Rabenh.

11. Closterium eboracense (Ehr.) Turner

12, 13. Closterium leiblenii Kütz. 

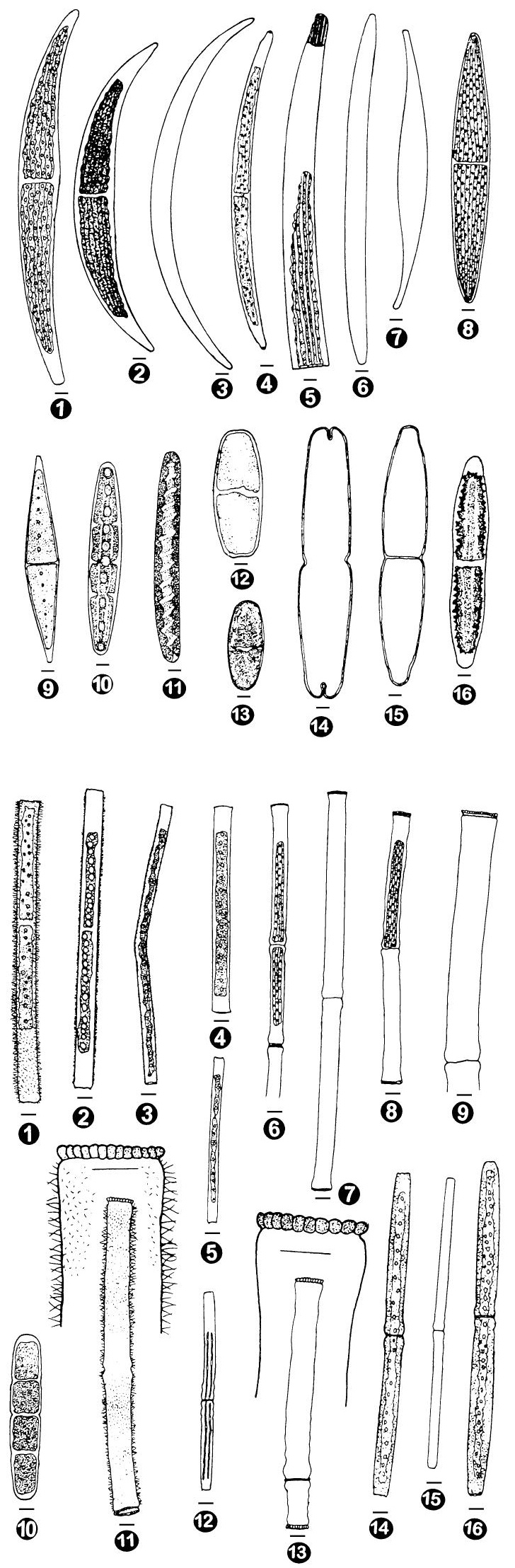

Fig. 4.

1-2. Closterium ehrenbergii Menegh. Ex. Ralfs

3. Closterium dianae Ehr.

4, 5. Closterium turgidum Ehr. var. borgei (Borge) Defl.

6. Closterium acerosum (Schr.) Ehr. var. elongatum Breb.

7. Closterium rostratum Ehr.

8. Closterium lanceolatum Kütz. in Ralfs

9. Closterium rostratum Ehr. var. brevirostratum W. West

10. Closterium leibellula Focke var. interruptum (W. .\& G.S. West) Donat

11. Spirotaenia condensata Breb. in Ralfs

12, 13. Cylindrocystis brebissonii Menegh.

14, 15. Tetmemorus brebissonii (Menegh.) Ralfs

16. Netrium digitus (Ehr.) Itzigs. \& Rothe var. lamellosum (Breb.) Grönbl.
Fig. 5.

1. Gonatozygon aculeatum Hast.

2, 3. Gonatozygon pilosum Wolle

4. Gonatozygon kinhanii (Arch.) Rabenh. f. minor Forster

5. Gonatozygon monotaenium De Bary var. angustum Forster

6. Pleurotaenium subcoronulatum (Turn.) W. \& G.S. West var. africanum Schmid.

7. Pleurotaenium simplissimum Grönbl. var. simplissimum Krieger

8, 9. Pleurotaenium maculatum (Turn.) Krieger

10. Penium margaritaceum (Ehr.) ex Breb. in Ralfs

11. Pleurotaenium subcoronatum (Turn.) W. \& G.S. West var. spinulosum var. nova

12. Pleurotaenium coronatum (Breb.) var. nodulosum (Breb.) W. \& G.S. West f. constrictum Krieger

13. Pleurotaenium subcoronatum (Turn.) W. \& G.S. West

14, 15. Pleurotaenium baculoides (Roy \& Biss.) Playfair

16. Pleurotaenium trabercula (Ehr.) Naegeli in Krieger 

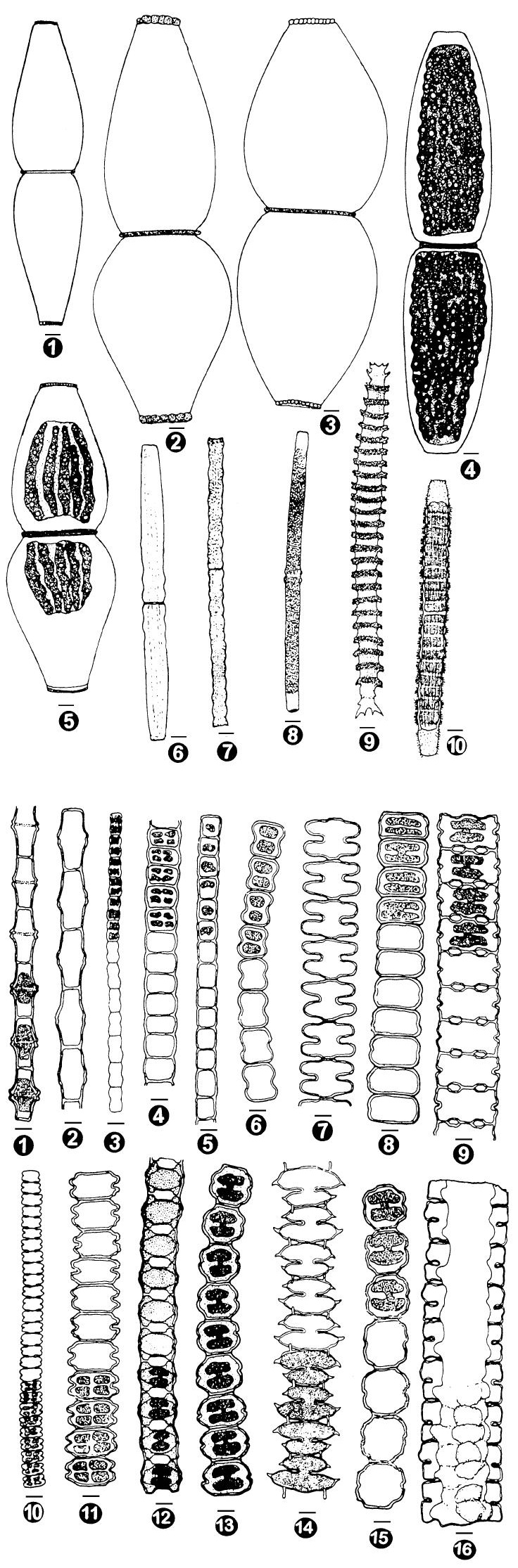

Fig. 6.

1. Pleurotaenium ovatum Nordst.

2. Pleurotaenium ovatum Nordst. var. tumidum (Mask..) G.S. West

3. Pleurotaenium ovatum Nordst. var. elephantinum (Cohn) Krieger

4. Pleurotaenium ovatum Nordst. var. tumidum (Mask.) G.S. West

5. Pleurotaenium ovatum Nordst. var. inermius Mobius

6. Pleurotaenium coronatum (Breb.) Rabenh.

7. Pleurotaenium coronatum (Breb.) Rabenh. var. fluctuatum W. West

8. Pleurotanium trabercula (Ehr.) Naeg. in Krieger var. rectum (Delp.) W. \& G.S West

9. Triploceras gracile Bail. var. bidentum Nordst. in Krieger

10. Penium spinulosum (Wolle) Gerrath

Fig. 7.

1. Bambusinia brebissonii Kütz.

2. Bambusinia borreri (Ralfs) Delp. var. grassiliscens (Nordst.) Wolle

3. Hylotheca undulata Nordst. var. perundulata Gronbl.

4, 5. Hylotheca dissiliens (Smith) Breb. in Ralfs

6. Spondylosum planum (Wolle) W. \& G.S. West

7. Spondylosum pulchrum (Bail.) Arch. in Smith

8. Desmidium quadratum Nordst.

9. Desmidium aptogonium Breb. var. tetragonum W. \& G.S. West

10, 11. Desmidium swartzii Agardh

12. Desmidium baileyi (Ralfs) Nordst.f. tetragonum Nordst.

13. Desmidium coarctatum Nordst. var. cambricum W. West

14. Onychonema laeve Nordst. var. latum W. \& G. S. West

15. Desmidium grevillei (Kütz.) De Bary

16. Phymatodocis irregulare Schmid. var. intermedia Gutw. 


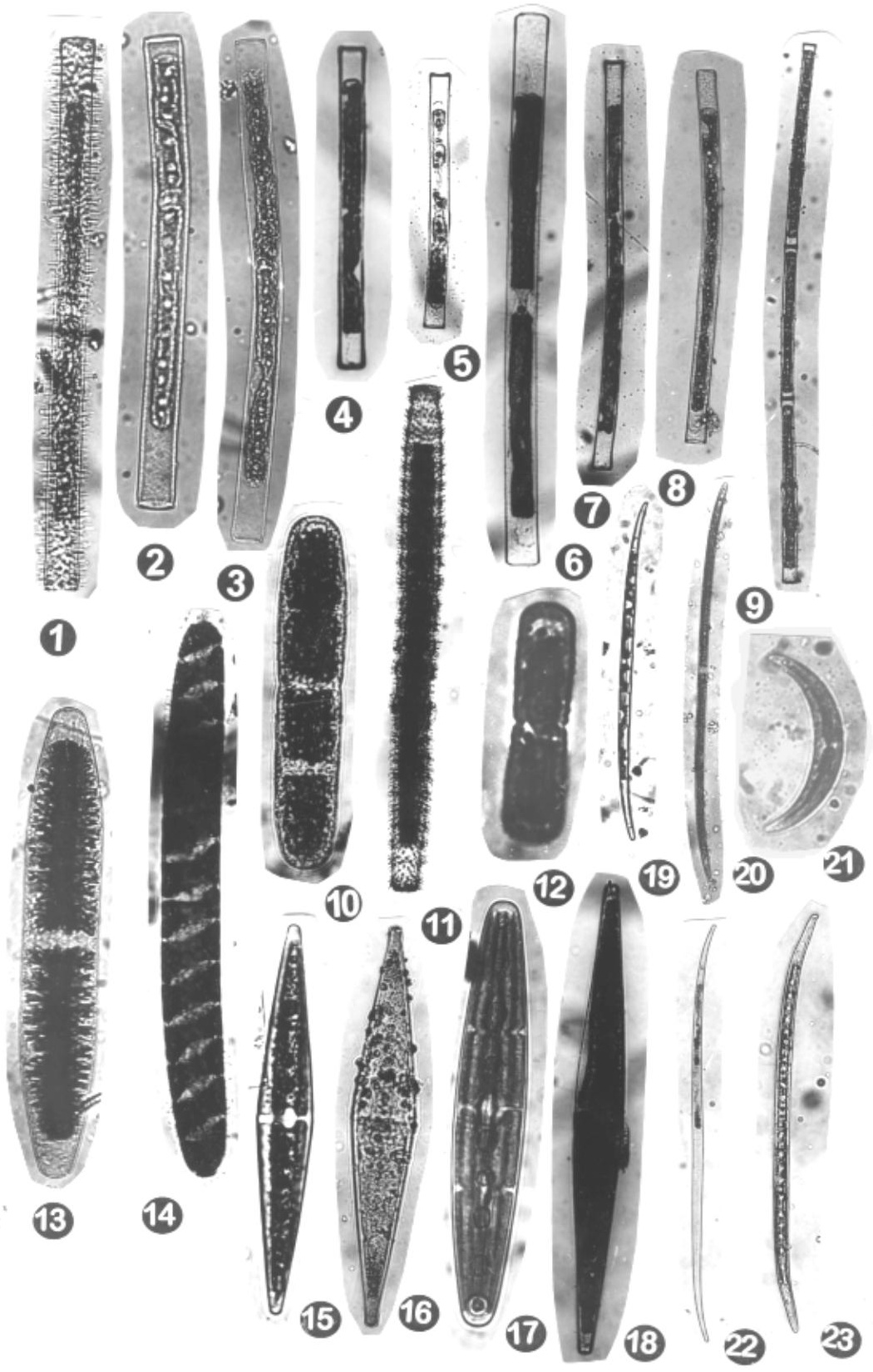

Plate 1.

1. Gonatozygon aculeatum Hast. (x555)

2, 3. Gonatozygon kinahanii (Arch.) Rabenh. var. interruptum Forster $(2 \times 231 ; 3 \times 233)$

4, 5. Gonatozygon kinahanii (Arch.) Rabenh. f. minor Forster (4 $\mathrm{x} 375 ; 5 \times 287)$

6. Gonatozygon monotaenium De Bary (x 311)

7, 8. Gonatozygon monotaenium De Bary var. angustum Forster $(7 \times 297 ; 8 \times 312)$

9. Genicularia elegans W. \& G. S. West (x476)

10. Penium cylindrus (Ehr.) Breb. in Ralfs (x510)

11. Penium spinulosum (Wolle) Gerrath (x210)

12. Penium margaritaceum (Ehr.) Breb. in Ralfs ( $\mathrm{x} 460)$

13. Netrium digitus (Ehr.) Itzigs. \& Rothe var. lamellosum (Breb.) Grönbl. (x346)
14. Spirotaenia condensata Breb. in Ralfs (x631)

15,16 . Closterium rostratum Ehr. var. brevirostratum W. West $(15 \times 286 ; 16 \times 307)$

17. Closterium libellula Focke var. interruptum (W. \& G. S. West) Donat (x757)

18. Closterium rectimarginatum Scott \& Pres. (x 299)

19. Closterium gracile var. Breb. (x529)

20. Closterium gracile Breb. (x223)

21. Closterium incurvum Breb. (x723)

22. Closterium pronum Breb. (x230)

23. Closterium lineatum Ehr. (x234) 


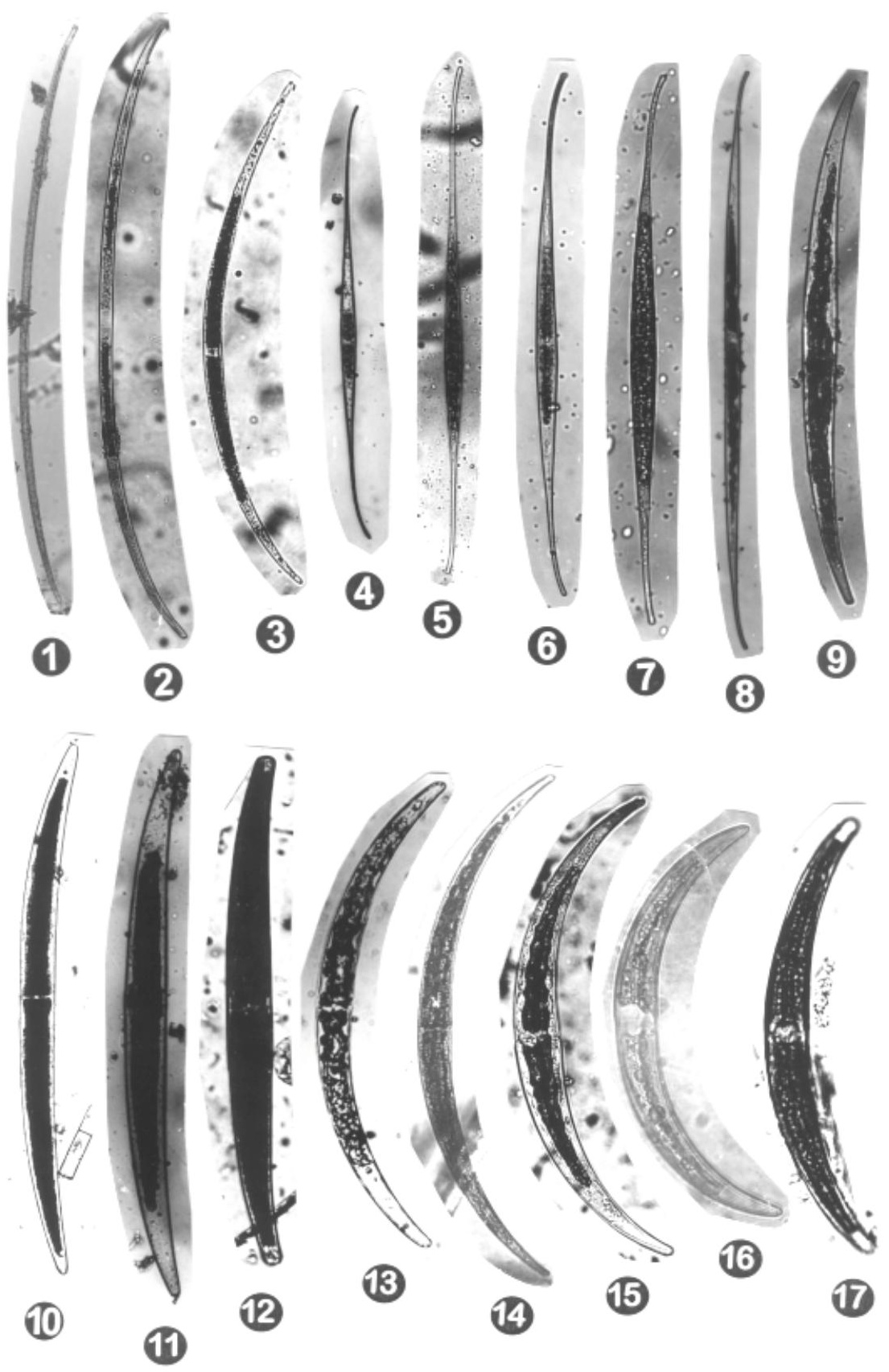

Plate 2.

1, 2. Closterium aciculare T. W. West (1x143; 2x140)

3. Closterium lineatum Ehr. var. curvatum Thom. (228)

4, 5. Closterium setaceum Ehr. in Ralfs (4x218; 5x206)

6, 7. Closterium kuetzingii Breb. (6x245; 7x208)

8. Closterium kuetzingii Breb. var. kuetzingii f. croasdale Forster (x211)

9. Closterium ralfsii Breb.var. hybridum Rabenh.

10, 11. Closterium acerosum (Schr.) Ehr. (9x250; 10x259)
12. Closterium striolatum Ehr. (x265)

13. Closterium dianae Ehr. (x608)

14. Closterium dianae Ehr. var. pseudodianae (Roy) Krieger (x300)

15. Closterium dianae Ehr. var. arcuatum (Breb.) Rabenh. (x260) 16. Closterium cynthia De Not. (x605)

17. Closterium calosporum Wittr. (x552) 

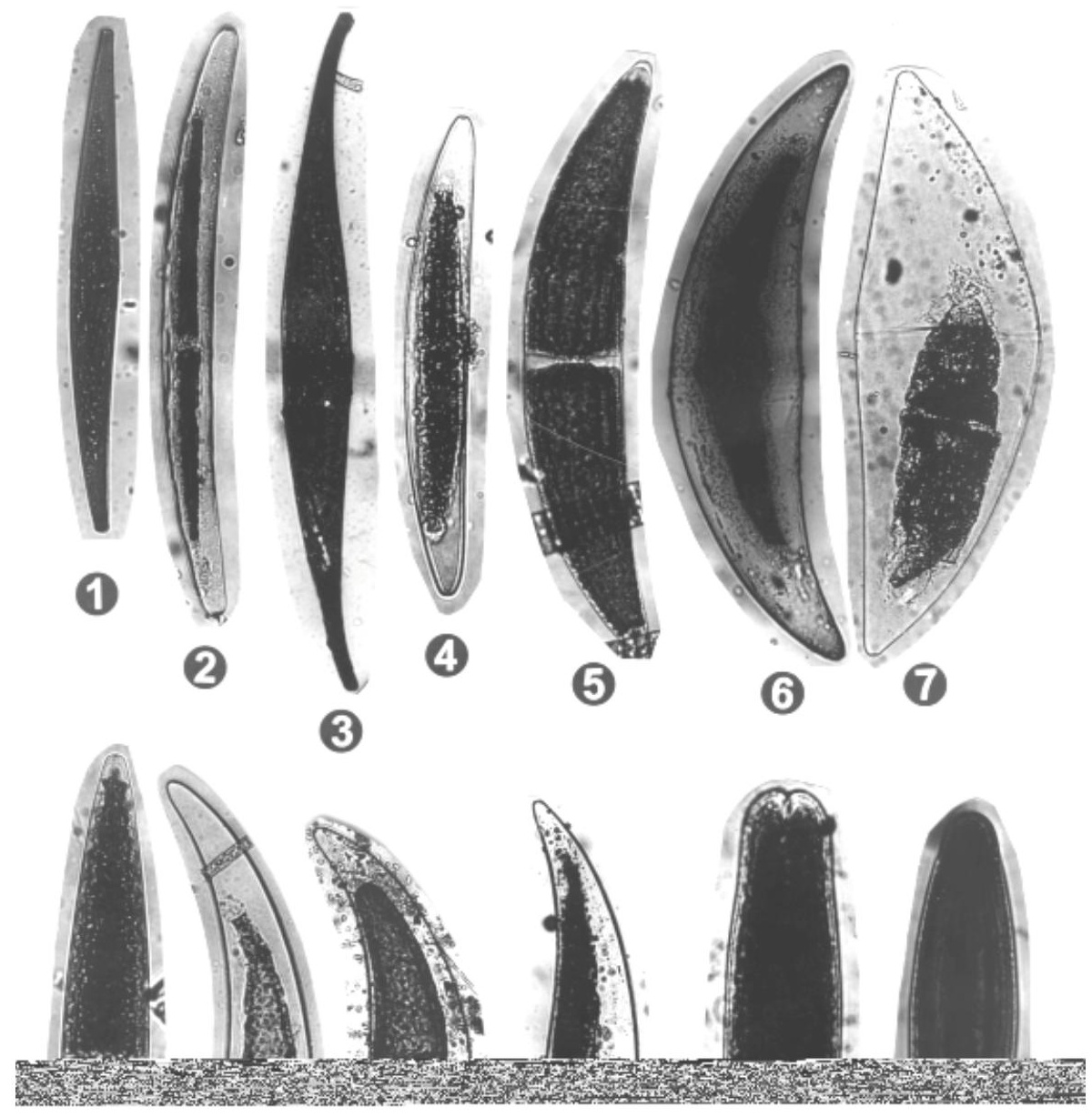

Plate 3.

1. Closterium costatum Corda var. westii Cush. (x300)

2. Closterium turgidum Ehr. var. borgei (Borge) Defl. (x133)

3. Closterium rostratum Ehr. (x252)

4. Closterium pseudolunula Borge var. concavum Forster \& Eckert (x197)

5. Closterium lunula (Müll.) Nitsch ex Ralfs (x165)

6. Closterium lunula (Müll.) Nitsch var. maximum Borge (x190)
7. Closterium lunula (Müll.) Nitsch v. maximum Borge f. crassissimum Croasd. (x150)

8. Closterium lanceolatum Kütz. in Ralfs (x194)

9, 10. Closterium ehrenbergii Menegh.Ex Ralfs (9x145; 10x158)

11. Closterium monoliferum (Bory) Ehr. ex Ralfs (x155)

12, 13. Tetmemorus brebissonii (Menegh.) Ralfs (12x350; $13 \times 348)$ 


\section{REFERENCES}

Agardh, C.A. 1824. Systema Algarum. Lund: 312 pp.

Agarkar, D.S. 1969. Contribution to the desmids of Gwalior, Madhya Pradesh (India). Phykos, 8: 1-10.

Agarkar, D.S. 1971. Contribution to the desmids of Gwalior, Madhya Pradesh (India). Phykos, 10: 54-69.

Agarkar, D.S. \& M.S. Agarkar. 1977. Desmids from Packmarhi, Madgya Pradesh, India. Hydrobiologia, 54(1): 2332.

Bailey, J.W. 1851 Microscopical observation made in South Carolina, Georgia and Florida. Smithsonian Knowledge, 2 (Art. 8): 1-48, Pls. 1-3.

Bharati, S.S. \& K.M. Pai. 1972. Some desmids from Kodaikanal Lake, South India. Phykos, 11: 27-36.

Bicudo, C.E.M. 1969. Contribution to the knowledge of the desmids of Sao Paulo, Brasil (including a few from the State of Minas Gerais). Nova Hedwigia, 17: 433-459.

Borge, O. 1903. Die Algen der ersten Regnell'schen Expedition, 2 . Desmidiaceen. Arkiv. Bot., 1(4): 71-138.

Borge, O. 1906. Susswasser-Chlorophyceen van Feuerland und Isls Desolacion. Bot. Stud. Tillägn. F.R. Kjellman, Uppsala.

Borge, O. 1911. Algologische Notizen 6-7. 6 Süsswasseralgen aus Queensland. Bot. Notiser, 1911: 197-207.

Bourrelly, P. 1957. Algues d'eau douce du Soudan Francais, region du Macina (A.O.F.). Bull. I.F.A.N., 19, Ser. A(4): $1047-1102+21 \mathrm{pls}$.

Bourrelly, P. 1961. Algues d'eau douce de la Republique de Cote d'Ivoire. Bull. I.F.A.N., 23, Ser. A(2): 283-374 Pls. $11-24$

Brebisson, A. de 1839. Sur le preparations necessaires a l'etude des alques inferienres and catalogue des especes connues des desmidiees, et des Diatomees ou Bacillariees in Chevelier Des Microscopes et de leur usage. Paris, 1839 Desmidiees. Pp. 271-273.

Brebisson, A. de 1844. Dict. Univ. d'Hist. Nat. Paris.

Brebisson, A. de 1856. Liste des Desmidiées observées en Basse-Normandie. Mem. Soc. Imp. Sci. Naturf. Cherbourg., 4: 113-166; 301-304. Pls. 1, 2.

Brook, A.J. 1965. Planktonic Algae as Indicators of Lake Types, with special reference to the Desmidiaceae. Limnol. Oceanogr., 10: 403-411.

Brook, A., J. Fotheringham, J. Bradly and A. Jenkins 1980. Barium accumulation by desmids of the genus Closterium. Br. Phyol J., 15. 261-264.

Brunnel, J. 1949. The rediscovery of the desmid Pleurotaenium spinulosum with description of a new variety from Madagascar. Contr. Inst. Bot. Univ. Montreal, 64: 3-19.

Cohn, F. 1879. Desmidiaceae Bongoenses. Festschr. Feier hundertjahr. Bestehen naturforsch. Ges. Halle a.S., pp. 259-272 (sep. p. 1-14), Pl. 11.

Compere, P. 1967. Algues du Sahara et de la region du Lac Tchad. Bull. Jard. Bot. Nat. Belg., 37: 109-288.

Compere, P. 1977. Algues du la region du Lac Tchad. 7. Chlorophycophytes (3e partie: Desmidiees). Cah. O.R S.T. M. Ser Hydrobiol, 11: 77-177.

Cook, P. 1963. Variation in vegetative and sexual morphology among the small curved species of Closterium. Phycologia, 3(1), 1-18. 20 Figs.

Coute, A. \& G. Rousselin. 1975. Contribution a l'etude des algues d'eau douce du Moven Niger (Mali). Bull. Mus. Nat. Hist. Nat. Paris, 3e ser., Bot. 21: 73-175.

Croasdale, H.T. \& E.A. Flint 1986. Flora of New Zealand. Freshwater Algae, Chlorophyta, Desmids with ecological comments on their habitats. Vol. 1, Govt. Printer, Wellington.

Croasdale, H.T., \& R. Grönblad 1964. Desmids of Labrador I. Desmids of the Southeastern coastal area. Trans. Amer. Microsc. Soc., 83 (2), 142-212, Pls. 1-21.
Cushman, J.A. 1908. The New England species of Closterium. Bull. Torrey Bot. Club, 35, 109-134, Pls. 3-5.

De Bary, A. 1856. Zu Gonatozygon monotaenium, Hedwigia, 1(16): 105-106.

De Bary, A. 1858. Untersuchungen über die Familie der Conjugaten. (Zygnemaceen und Desmidieen). Leipzig: 91 pp.

Deflandre, G. 1924. Additions a la flore des environs de Paris. Bull. Soc. Bot. France, 71: 911-921.

De Notaris, G. 1867. Elementi per lo studio delle Desmidiacee Italiche. Genova: 84 pp. 9 Pls.

Donat, A. 1926. Zur Kenntnis der Desmidiaceen des norddeutschen Flachlandes. Pflanzenforschung, 5: 1-51, Pls. 1-5.

Ehrenberg, C.G. 1828. Symbolae physicae seu icones et descriptiones animalium et vertebratorum. Decas Prima, Berlin 1828 .

Ehrenberg, C.G. 1838. Die Infusionsthierchen als vollkommene Organismen. Leipzig: 548 pp., 64 Pls.

Forster, K. 1963. Desmidiaceen aus Brasilien. I. Nord-Brasilien. Rev. Algol. N.S., 7(1): 38-92

Forster, K. 1964. Einige Desmidiaceen aus der Umgebung von Addis Abeba. Rev. Alg. N.S., 7(3): 223-236.

Forster, K. 1969. Amazonische Desmidiaceen. 1. Teil. Areal Santarém. Amazonia, 11 (1/2): 5-116 + pls. 56.

Forster, K. 1982. Conjugataceae, Zygnematales und Desmidiales (excl. Zygnemataceae). In: G. Huber-Pestalozzi (Ed.), Die Binnengewasser XVI. Das Phytoplankton des Süsswassers. Schweizerbat'sche Verlagsbuchandlung, Stuttgart, 8, 1-43.

Fritsch, F.E. \& F. Rich. 1937. Contribution to our knowledge of the freshwater algae of Africa. 13. Algae from the Belfast Pan, Transvaal. Trans. Roy. Soc. S. Africa, 25(2): 153228.

Gerrath, T.F. 1969. Penium spinulosum (Wolle) comb. nova. (Desmidiaceae): a taxonomic correction based on cell wall ultrastructure. Phycologia, 8(2): 109-118.

Gerrath, T.F. \& D.M. John. 1988. The desmids of Ghana, West Africa. 1. Nova Hedwigia, 46: 187-230.

Grönblad, R. 1920. Finnlandische Desmidiaceen aus Keuru. Acta Soc. Fauna et Flora Fenn., 47(4): 1-98 Pls. 1-6.

Grönblad, R. 1921. New desmids from Finland and northern Russia with critical remarks on some known species. Acta Soc. Fauna Flora Fenn., 49(7): 1-78. Pls. 1-7.

Grönblad, R. 1938. Neue und seltene Desmidiaceen. Bot. Notiser, 1938 (1/3): 49-66.

Grönblad, R. 1960. Contributions to the knowledge of the freshwater algae of Italy. Soc. Sci. Fennica. Comm. Biol., XXII (4): 1-85.

Grönblad, R. 1962. Sudanese Desmids II. Acta Bot. Fennica, 63: 1-19.

Grönblad, R. \& H.T. Croasdale. 1971. Desmids from Namibia (S.W. Africa). Acta Bot. Fennica, 93: 1-40.

Grönblad, R., G.A. Prowse \& A.M. Scott. 1958. Sudanese desmids. Acta Bot. Fenn., 58: 1-82.

Grönblad, R., A.M Scott \& H.T. Croasdale. 1964. Desmids from Uganda and Lake Victoria. Acta Bot. Fennica, 66: 157.

Grönblad, R., A.M Scott \& H.T. Croasdale. 1968. Desmids from Sierra Leone, tropical West Africa. Acta Bot. Fennica, 78: 1-41.

Gutwinski, R. 1902. De Algis a M. Raciborski anno 1899 in Insula Java collectis. Bull. Akad. Sci. Cracovie, 9: 575617.

Hardy, A.D. 1906. The freshwater algae of Victoria. In: Desmids by G.S. West. Part 3. The Victorian Naturist, Melborne, 23: 18-22; 33-42.

Hastings, W.N. 1892. A proposed new desmid. Amer. Monthly Microsc. Journ., 13(2): 29, Text fig. 
Hemians, J. 1946. On Closteriometry. Biol. Jaahrb. Dodonaea, 13: 146-154. Text Figs. 1-4.

Hirano, M. 1972. Desmids from Cambodia with special reference to phytoplankton of Lake Grands Lacs (Tonle sap.). Contr. Biol. Lab. Kyoto Univ., 22: 123-157 + 13 pls.

Huber-Pestalozzi, G. 1982. Die Binnengewasser XVI. Das Phytoplankton des Süsswassers. 8. Schweizerbat'sche Verladsbuchhandlung. Stuttgart: $543 \mathrm{pp}$.

Irenee-Marie, Fr. 1939. Flore desmidiale de la region Montreal. Laprairie, Canada: 547 pp. 69 Pls.

Islam, A.K.M.N. 1970. Contribution to the knowledge of desmids of East Pakistan. Part I. Nova Hedwigia, 20: $903-$ 983.

Islam, A.K.M.N. \& A.K.Y. Haroon. 1980. Desmids of Bangledesh. Int. Rev. ges. Hydrobiol., 64(4): 551-604.

Islam, A.K.M.N. \& A.K.Y. Haroon. 1985. Desmids of Iraq Int. Rev. ges. Hydrobiol., 70(6): 877-889.

Islam, A.K.M.N. \& K.M. Zaman. 1975. Limnological studies on the river Burigango. III. Biological aspect. J. Asiatic Soc. Bangledesh, 1: 45-65.

Itzigsohn, H. \& Rothe 1856. In: Rabenhorst. L. Algen (no. 508).

John, D.M. 1986. The inland waters of tropical West Africa: An introduction and botanical review. Arch. Hydrobiol. Beih., 23: 1-244.

Kadiri, M.O. 1987. Algae and Primary Productivity Studies of Ikpoba Reservoir. Ph.D. Thesis, University of Benin, Benin City, Nigeria.

Kadiri, M.O. 1988. A taxonomic study of the genus Closterium (Nitsch, 1817) Ralfs 1848 (Desmidiaceae; Chlorophyta) in a small Nigerian reservoir with ecological notes. Trop. Freshwat. Biol., 1(1): 71-90.

Kadiri, M.O. \& F.I. Opute. 1989. A rich flora of Micrasterias from the Ikpoba Reservoir, Nigeria. Arch. Hydrobiol., 116(3): 391-399.

Kaiser, P.E. 1931. Desmidiaceen des Berchtesgadener Landes III. In: Kryptogamen Forsch. 2(2).

Khan, M.A. 1984. Contribution to freshwater algae of Nigeria. 1. Some Jos Plateau Desmids. Nova Hedwigia, 39: $293-$ 296.

Krieger, W. 1932-1933. Die Desmidiaceen der Deutschen Limnologischen Sunda-Expedition. Arch. Hydrobiol. Suppl., 11: 129-230, Pls 3-26.

Krieger, W. 1937. Die Desmidiaceen Europas mit Berücksichtigung der ausser-europaischen Arten. Rabenhorst's Kryptogamen-Flora Dt. Osterreich und der Schwetz, 13(2), 1. Teil, Lief 3/4: 376-712. Pls 37-96.

Krieger, W. 1939. Die Desmidiaceen Europas mit Berücksichtigung der ausser-europaischen Artem. Rabenhorst's Kryptogamen-Flora von Deutschland Osterreich und der Schweiz, 13(2): 2 Teil: Lief 5: 1-117, Pls 97-142.

Kützing, F.I. 1845. Phycologia germanica, d.i. Deutschlands Algen in bundigen Deschreibungen, Nordhausen: X +340 pp.

Kützing, F.I. 1847. Tabulae phycologicae oder Abbildungen der Tange, Nordhausen:1 (3/5): 17-36, Pls 21-50.

Lind, E.M. 1967. Some East African Desmids. Nova Hedwigia, 13: 361-387.

Lind, E.M. 1971. Some Desmids from Uganda. Nova Hedwigia, 22(1/2): 535-585.

Lind, E.M. \& A.J. Brook. 1980. Desmids of the English Lake District. Freshwater Biological Association Scientific Publication No. 42: 143 pp.

Ling, H.U. \& P.A. Tyler. 1986. A limnological survey of the Alligator Rivers Region. II. Freshwater algae exclusive of diatoms. Alligator Rivers Region Research Institute, Research Report No. 3: 1-173.

Meneghini, G. 1838. Cenni sulla organografia e fisiologia delle alghe. Nuovi saggi R. Accad. Sci. Lett. Arti, Padua, 4: 324-388.
Mobius, M. 1894. Australische Süsswasseralgen II. Abh. Senckenberg Naturf. Ges., 18: 310-350.

Naegeli, C. 1849. Gattungen einzelliger Algen physiologisch und systematisch be arbeitet. Neue Denkschr. d'allg. Schuetz Gesllsch f.d. Ges. Naturwissensch, 10: 1-139, 8 Pls Zurich.

Nordstedt, O. 1873. Bidrag till Kannedomen om Sydligare Norges Desmidiéer. Acta Univ. Lund, (1872) 9: 1-51, 1 pl.

Nordstedt, O. 1877. Nonnulae algae aquae dulcis brasilienses. Öfv Kongl. Svenska Vet. Akad. Förhandl. 1877 (3): 1528, Pls. 2.

Nordstedt, O. 1888. Freshwater algae, collected by Dr. S. Berggren in New Zealand and Australia. Kongl. Svenska Vet. Akad.. Handl., 22(8): 1-98. Pls. 1-7.

Opute, F.I. 1985. Phytoplankton Profile and Periodicity in the Warri/Forcados Estuaries of Southern Nigeria. Proc. UNESCO/IABO Symposium on the Comparative Ecology of Aquatic Environments, Nairobi, Kenya.

Opute, F.I. (1990). Phytoplankton flora in the Warri/Forcados Estuary of Southern Nigeria. Hydrobiologia, 208: 101109.

Opute, F.I. 1992 Contribution to the knowledge of algae of Nigeria. I. Desmids from the Warri/Forcados Estuaries. Part II. The genera Euastrum and Micrasterias. Algological Studies, 65: 73-92.

Oye, P. van 1953. Contribution a la connaissance des Desmidiacees du Congo Belge. Hydrobiologia, 5: 239-308.

Parra, U. 1975. Desmidiaceas de Chile I. Desmidiaceas de la region de Concepcion y Alrededores. Gayana Inst. Biol. Bot., Univ. Concepcion, Chile, 30: 1-90.

Playfair, G.I. 1907. Some new or less known desmids found in New South Wales. Proc. Linn. Soc. N.S.W., 32: 160-221.

Prescott, G.W. 1966. Algae of the Panama Canal and its tributaries. II. Conjugales Phykos, 5: 1-49.

Prescott, G.W., C.E. Bicudo \& W.C. Vinyard 1982. A Synopsis of North American Desmids. Part II. Desmidiaceae: Placodermae. Univ. Nebraska Press, Lincoln. Section 4: $700 \mathrm{pp}$.

Prescott, G.W., H.T. Croasdale \& W.C. Vinyard. 1975. A Synopsis of North American Desmids. Part II. Desmidiaceae: Placodermae. Univ. Nebraska Press, Lincoln, Section 2: $413 \mathrm{pp}$.

Prescott, G.W., H.T. Croasdale, W.C. Vinyard \& C.E. Bicudo. 1981. A Synopsis of North American Desmids. Part II. Desmidiaceae: Placodermae. Univ. Nebraska Press, Lincoln, Section 3: $720 \mathrm{pp}$.

Rabenhorst, L. 1863. Kryptogamenflora von Sachsen, der Ober-Lausitz, Thüringen und Nordböhmen mit Berucksichtigung der benachbarten Lander. I. Abt. Aigen im weitesten Sinne, Leberund Laubmoose. Leipzig: xx + 653 pp.

Rabenhorst, L. 1868. Flora Europaea Algarum aquae dulcis et submarinae. Sect. 3. Algae Chlorophyllophyceas melanophyceas et Rhodophyceas complectans. Leipzig: $\mathrm{xx}+461$ pp.

Ralfs, J. 1844. On the British Desmidiaceae. Ann. Mag. Nat. Hist., 14: 187; 194; 256-261; 391-396.

Ralfs, J. 1848. The British Desmidiaceae. London: xxii +226 pp., 35 Pls.

Rich, F.E. 1932. Contributions to our knowledge of freshwater algae of Africa. 10. Phytoplankton from South African Pans and Vlais. Trans. Roy. Soc. S. Africa, 20: 149-188.

Roy, J. \& J.P. Bisset 1886. Notes on Japanese Desmids. Journ. Bot., 24: 193-196, $1 \mathrm{Pl}$

Ruzicka, J. 1977. Die Desmidiaceen Mitteleuropas. 1. E. Schweizerbart'sche Verlagsbuchhandlung, Stuttgart.: 291 pp., 44 Pls.

Ruzicka, J. 1981. Die Desmidiaceen Mitteleuropas 1(2). E. Schweizerbart'sche Verlagsbuchhandlung, Stuttgart.: i-ix: 298-736, Pls. 45-117. 
Schmidle, W. 1902. Algen, insbesondere solche des Plankton aus dem Nyassasee und Seiner Umgebung gesammelt von Dr. Fülleborn. Engler's Bot. Jahrb., 32: 56-88.

Scott, A.M. \& R. Grönblad. 1957. New and interesting desmids from the Southeastern United States. Acta Soc. Sci. Fenn., n.s., B. 2: 1-62.

Scott, A.M., R. Grönblad \& H.T. Croasdale. 1965. Desmids from the Amazon basin, Brasil, collected by Dr. H. Sioli. Acta Bot. Fennica, 69: 1-94.

Scott. A.M. \& G.W. Prescott. 1958. Some freshwater algae from Arnhem land in the Northern Territory of Australia. Records American-Australia Sci. Exped. Arnhem Land 3. 8-136, Pls 1-29, 1 Map, Melborne University Press.

Scott. A.M. \& G.W. Prescott. 1961. Indonesian Desmids, Hydrobiologia, 17(1/2): 1-132.

Sinha, J.P. \& G.D. Mishra. 1967. Some desmids from Ranchi. Phykos, 6: 102-105.

Smith, G.M. 1924. Phytoplankton of the island lakes of Wisconson. Part II. Desmidiaceae. Bull. Wisc. Geol. Nat. Hist. Surv., 57(ii): 1-227.

S.P.D.C. 1988. Shell Petroleum Development Company, Western Division, Warri Nigeria. (Personal communication).

Suxena, M.R. \& V. Venkateswarlu. 1970. Desmids of Andhra Pradesh. V. Mostly from Warangal and its environs. Phykos, 9: 17-28.

Thomasson, K. 1957. Notes on the plankton of Lake Bangweulu. Nova Acta Reg. Soc. Sci. Upsal. Ser. 4, 17(3): $1-18$.

Thomasson, K. 1960. Notes on the plankton of Lake Bangweulu. Part 2. Nova Acta Soc. Sci. Upsal. Ser. 4 17(12): 1-43.

Thomasson, K. 1963. Araucanian Lakes. Plankton Studies in North Patagonia, with notes on terrestrial vegetation. Acta Phytogeogr. Suecica, 47: 1-139, 47 figs.

Thomasson, K. 1965. Notes on algal vegetation of Lake Kariba. Nova Acta Soc. Sci. upsal., Ser. 4, 19(1): 1-34.

Thomasson, K. 1966. Phytoplankton of Lake Shiwa Ngandu. Expl. Hydrobiol. Bangweolo-Luapula. IV. Fas. 2: 1-90, 21 Pls.

Thomasson, K. 1967. Phytoplankton from Lakes on Mt. Wilhelm, East New Guinea. Blumba, 15(2): 285-296.

Thomasson, K. 1971. Amazonian algae. Mem. Inst. Roy. Sci. Nat. Beig., Ser. 2, 86: 1-57.

Thomasson, K. 1973. Notes on the plankton of some Sydney reservoirs, with description of two interesting desmids. Contr. N.S.W. Nat. Herb., 4: 344-394.
Turner, W.B. 1892. Algae aquae dulcis Indiae orientalis. The freshwater algae (principally Desmidiaceae) of East India. Kongl. Svenska Vet. Acad. Handl., 25(5): 1-187.

Vidyavati \& J. Nizam. 1970. Conjugation studies in Euastrum spinulosum Delp. var. duplominor. Phykos, 9: 139-147.

Wallich, G.C. 1860. Descriptions of Desmidiaceae from Lower Bengal. Ann. Mag. Nat. Hist., 111(5): 184-197.

West, G.S. 1907. Report on the freshwater algae, including phytoplankton of the Third Tanganyikan Expedition, conducted by Dr. W.A. Cunnington, 1904-1905. Journ. Linn. Soc. (Bot.), 38: 81-197.

West, T. 1860. Remarks on some Diatomaceae new or imperfectly described and on a new Desmid. Trans. Roy. Microsc. Soc., II, 8: 147-153, Pls 7:16.

West, W. 1890. Contribution to the freshwater algae of North Wales. Journ. Roy. Microsc. Soc., 6: 277-306, Pls 5, 6.

West, W. 1892. A contribution to the freshwater algae of North Ireland. Journ. Linn. Soc. Bot., London, 29: 103216.

West, W. \& G.S. West. 1895. A contribution to our knowledge of the freshwater algae of Madagascar. Trans. Linn. Soc. London, Bot. Ser. 5 (2): 41-90, Pls. 5-9.

West, W. \& G.S. West. 1896. On some North American Desmids. Trans. Linn. Soc. Bot., Ser. 2, 5: 229-294.

West, W. \& G.S. West. 1902. A contribution to the freshwater algae of Ceylon. Trans. Linn. Soc. Lond., Ser. 11(6): 123215.

West, W. \& G.S. West. 1904. A monograph of the British Desmidiaceae. Vol. 1, xxxvi + 224 pp., 32 Pls. Ray Society, London.

West, W. \& G.S. West. 1912. On the periodicity of the phytoplankton of some British Lakes. Journ. Linn. Soc. (Bot.), 40.

West, W., G.S. West \& N. Carter. 1904-1923. A monograph of the British Desmidiaceae. Vol. V., The Ray Society, London.

Wittrock, W.B. 1869. Anteckningar om Skandinaviens desmidiéer, Nova Acta Soc. Sci. Upsala, 3(7): 2-72.

Wolle, F. 1881. American freshwater algae. VI. Bull. Torrey Bot. Club, 8: 1-4.

Wolle, F. 1882. Freshwater algae. VI. Bull. Torrey Bot. Club, 9(3), 25-30, P1. 13.

Wolle, F. 1892. Desmids of the United States and List of American Pediastrums. Bethlehem. $\mathrm{Pa}$ 2nd. ed.: $169 \mathrm{pp}$.

Yacubson, S. 1973. El Fitoplankton de la laguna de san Javier del Valle (Esta Merida) Venezuela. Rev. Alg. N.S., 11: 91131. 
Schmidle, W. 1902. Algen, insbesondere solche des Plankton aus dem Nyassasee und Seiner Umgebung gesammelt von Dr. Fülleborn. Engler's Bot. Jahrb., 32: 56-88.

Scott, A.M. \& R. Grönblad. 1957. New and interesting desmids from the Southeastern United States. Acta Soc. Sci. Fenn., n.s., B. 2: 1-62.

Scott, A.M., R. Grönblad \& H.T. Croasdale. 1965. Desmids from the Amazon basin, Brasil, collected by Dr. H. Sioli. Acta Bot. Fennica, 69: 1-94.

Scott. A.M. \& G.W. Prescott. 1958. Some freshwater algae from Arnhem land in the Northern Territory of Australia. Records American-Australia Sci. Exped. Arnhem Land 3. 8-136, Pls 1-29, 1 Map, Melborne University Press.

Scott. A.M. \& G.W. Prescott. 1961. Indonesian Desmids, Hydrobiologia, 17(1/2): 1-132.

Sinha, J.P. \& G.D. Mishra. 1967. Some desmids from Ranchi. Phykos, 6: 102-105.

Smith, G.M. 1924. Phytoplankton of the island lakes of Wisconson. Part II. Desmidiaceae. Bull. Wisc. Geol. Nat. Hist. Surv., 57(ii): 1-227.

S.P.D.C. 1988. Shell Petroleum Development Company, Western Division, Warri Nigeria. (Personal communication).

Suxena, M.R. \& V. Venkateswarlu. 1970. Desmids of Andhra Pradesh. V. Mostly from Warangal and its environs. Phykos, 9: 17-28.

Thomasson, K. 1957. Notes on the plankton of Lake Bangweulu. Nova Acta Reg. Soc. Sci. Upsal. Ser. 4, 17(3): $1-18$.

Thomasson, K. 1960. Notes on the plankton of Lake Bangweulu. Part 2. Nova Acta Soc. Sci. Upsal. Ser. 4 17(12): 1-43.

Thomasson, K. 1963. Araucanian Lakes. Plankton Studies in North Patagonia, with notes on terrestrial vegetation. Acta Phytogeogr. Suecica, 47: 1-139, 47 figs.

Thomasson, K. 1965. Notes on algal vegetation of Lake Kariba. Nova Acta Soc. Sci. upsal., Ser. 4, 19(1): 1-34.

Thomasson, K. 1966. Phytoplankton of Lake Shiwa Ngandu. Expl. Hydrobiol. Bangweolo-Luapula. IV. Fas. 2: 1-90, 21 Pls.

Thomasson, K. 1967. Phytoplankton from Lakes on Mt. Wilhelm, East New Guinea. Blumba, 15(2): 285-296.

Thomasson, K. 1971. Amazonian algae. Mem. Inst. Roy. Sci. Nat. Beig., Ser. 2, 86: 1-57.

Thomasson, K. 1973. Notes on the plankton of some Sydney reservoirs, with description of two interesting desmids. Contr. N.S.W. Nat. Herb., 4: 344-394.
Turner, W.B. 1892. Algae aquae dulcis Indiae orientalis. The freshwater algae (principally Desmidiaceae) of East India. Kongl. Svenska Vet. Acad. Handl., 25(5): 1-187.

Vidyavati \& J. Nizam. 1970. Conjugation studies in Euastrum spinulosum Delp. var. duplominor. Phykos, 9: 139-147.

Wallich, G.C. 1860. Descriptions of Desmidiaceae from Lower Bengal. Ann. Mag. Nat. Hist., 111(5): 184-197.

West, G.S. 1907. Report on the freshwater algae, including phytoplankton of the Third Tanganyikan Expedition, conducted by Dr. W.A. Cunnington, 1904-1905. Journ. Linn. Soc. (Bot.), 38: 81-197.

West, T. 1860. Remarks on some Diatomaceae new or imperfectly described and on a new Desmid. Trans. Roy. Microsc. Soc., II, 8: 147-153, Pls 7:16.

West, W. 1890. Contribution to the freshwater algae of North Wales. Journ. Roy. Microsc. Soc., 6: 277-306, Pls 5, 6.

West, W. 1892. A contribution to the freshwater algae of North Ireland. Journ. Linn. Soc. Bot., London, 29: 103216.

West, W. \& G.S. West. 1895. A contribution to our knowledge of the freshwater algae of Madagascar. Trans. Linn. Soc. London, Bot. Ser. 5 (2): 41-90, Pls. 5-9.

West, W. \& G.S. West. 1896. On some North American Desmids. Trans. Linn. Soc. Bot., Ser. 2, 5: 229-294.

West, W. \& G.S. West. 1902. A contribution to the freshwater algae of Ceylon. Trans. Linn. Soc. Lond., Ser. 11(6): 123215.

West, W. \& G.S. West. 1904. A monograph of the British Desmidiaceae. Vol. 1, xxxvi + 224 pp., 32 Pls. Ray Society, London.

West, W. \& G.S. West. 1912. On the periodicity of the phytoplankton of some British Lakes. Journ. Linn. Soc. (Bot.), 40.

West, W., G.S. West \& N. Carter. 1904-1923. A monograph of the British Desmidiaceae. Vol. V., The Ray Society, London.

Wittrock, W.B. 1869. Anteckningar om Skandinaviens desmidiéer, Nova Acta Soc. Sci. Upsala, 3(7): 2-72.

Wolle, F. 1881. American freshwater algae. VI. Bull. Torrey Bot. Club, 8: 1-4.

Wolle, F. 1882. Freshwater algae. VI. Bull. Torrey Bot. Club, 9(3), 25-30, P1. 13.

Wolle, F. 1892. Desmids of the United States and List of American Pediastrums. Bethlehem. $\mathrm{Pa}$ 2nd. ed.: $169 \mathrm{pp}$.

Yacubson, S. 1973. El Fitoplankton de la laguna de san Javier del Valle (Esta Merida) Venezuela. Rev. Alg. N.S., 11: 91131. 
Schmidle, W. 1902. Algen, insbesondere solche des Plankton aus dem Nyassasee und Seiner Umgebung gesammelt von Dr. Fülleborn. Engler's Bot. Jahrb., 32: 56-88.

Scott, A.M. \& R. Grönblad. 1957. New and interesting desmids from the Southeastern United States. Acta Soc. Sci. Fenn., n.s., B. 2: 1-62.

Scott, A.M., R. Grönblad \& H.T. Croasdale. 1965. Desmids from the Amazon basin, Brasil, collected by Dr. H. Sioli. Acta Bot. Fennica, 69: 1-94.

Scott. A.M. \& G.W. Prescott. 1958. Some freshwater algae from Arnhem land in the Northern Territory of Australia. Records American-Australia Sci. Exped. Arnhem Land 3. 8-136, Pls 1-29, 1 Map, Melborne University Press.

Scott. A.M. \& G.W. Prescott. 1961. Indonesian Desmids, Hydrobiologia, 17(1/2): 1-132.

Sinha, J.P. \& G.D. Mishra. 1967. Some desmids from Ranchi. Phykos, 6: 102-105.

Smith, G.M. 1924. Phytoplankton of the island lakes of Wisconson. Part II. Desmidiaceae. Bull. Wisc. Geol. Nat. Hist. Surv., 57(ii): 1-227.

S.P.D.C. 1988. Shell Petroleum Development Company, Western Division, Warri Nigeria. (Personal communication).

Suxena, M.R. \& V. Venkateswarlu. 1970. Desmids of Andhra Pradesh. V. Mostly from Warangal and its environs. Phykos, 9: 17-28.

Thomasson, K. 1957. Notes on the plankton of Lake Bangweulu. Nova Acta Reg. Soc. Sci. Upsal. Ser. 4, 17(3): $1-18$.

Thomasson, K. 1960. Notes on the plankton of Lake Bangweulu. Part 2. Nova Acta Soc. Sci. Upsal. Ser. 4 17(12): 1-43.

Thomasson, K. 1963. Araucanian Lakes. Plankton Studies in North Patagonia, with notes on terrestrial vegetation. Acta Phytogeogr. Suecica, 47: 1-139, 47 figs.

Thomasson, K. 1965. Notes on algal vegetation of Lake Kariba. Nova Acta Soc. Sci. upsal., Ser. 4, 19(1): 1-34.

Thomasson, K. 1966. Phytoplankton of Lake Shiwa Ngandu. Expl. Hydrobiol. Bangweolo-Luapula. IV. Fas. 2: 1-90, 21 Pls.

Thomasson, K. 1967. Phytoplankton from Lakes on Mt. Wilhelm, East New Guinea. Blumba, 15(2): 285-296.

Thomasson, K. 1971. Amazonian algae. Mem. Inst. Roy. Sci. Nat. Beig., Ser. 2, 86: 1-57.

Thomasson, K. 1973. Notes on the plankton of some Sydney reservoirs, with description of two interesting desmids. Contr. N.S.W. Nat. Herb., 4: 344-394.
Turner, W.B. 1892. Algae aquae dulcis Indiae orientalis. The freshwater algae (principally Desmidiaceae) of East India. Kongl. Svenska Vet. Acad. Handl., 25(5): 1-187.

Vidyavati \& J. Nizam. 1970. Conjugation studies in Euastrum spinulosum Delp. var. duplominor. Phykos, 9: 139-147.

Wallich, G.C. 1860. Descriptions of Desmidiaceae from Lower Bengal. Ann. Mag. Nat. Hist., 111(5): 184-197.

West, G.S. 1907. Report on the freshwater algae, including phytoplankton of the Third Tanganyikan Expedition, conducted by Dr. W.A. Cunnington, 1904-1905. Journ. Linn. Soc. (Bot.), 38: 81-197.

West, T. 1860. Remarks on some Diatomaceae new or imperfectly described and on a new Desmid. Trans. Roy. Microsc. Soc., II, 8: 147-153, Pls 7:16.

West, W. 1890. Contribution to the freshwater algae of North Wales. Journ. Roy. Microsc. Soc., 6: 277-306, Pls 5, 6.

West, W. 1892. A contribution to the freshwater algae of North Ireland. Journ. Linn. Soc. Bot., London, 29: 103216.

West, W. \& G.S. West. 1895. A contribution to our knowledge of the freshwater algae of Madagascar. Trans. Linn. Soc. London, Bot. Ser. 5 (2): 41-90, Pls. 5-9.

West, W. \& G.S. West. 1896. On some North American Desmids. Trans. Linn. Soc. Bot., Ser. 2, 5: 229-294.

West, W. \& G.S. West. 1902. A contribution to the freshwater algae of Ceylon. Trans. Linn. Soc. Lond., Ser. 11(6): 123215.

West, W. \& G.S. West. 1904. A monograph of the British Desmidiaceae. Vol. 1, xxxvi + 224 pp., 32 Pls. Ray Society, London.

West, W. \& G.S. West. 1912. On the periodicity of the phytoplankton of some British Lakes. Journ. Linn. Soc. (Bot.), 40.

West, W., G.S. West \& N. Carter. 1904-1923. A monograph of the British Desmidiaceae. Vol. V., The Ray Society, London.

Wittrock, W.B. 1869. Anteckningar om Skandinaviens desmidiéer, Nova Acta Soc. Sci. Upsala, 3(7): 2-72.

Wolle, F. 1881. American freshwater algae. VI. Bull. Torrey Bot. Club, 8: 1-4.

Wolle, F. 1882. Freshwater algae. VI. Bull. Torrey Bot. Club, 9(3), 25-30, P1. 13.

Wolle, F. 1892. Desmids of the United States and List of American Pediastrums. Bethlehem. $\mathrm{Pa}$ 2nd. ed.: $169 \mathrm{pp}$.

Yacubson, S. 1973. El Fitoplankton de la laguna de san Javier del Valle (Esta Merida) Venezuela. Rev. Alg. N.S., 11: 91131. 
Schmidle, W. 1902. Algen, insbesondere solche des Plankton aus dem Nyassasee und Seiner Umgebung gesammelt von Dr. Fülleborn. Engler's Bot. Jahrb., 32: 56-88.

Scott, A.M. \& R. Grönblad. 1957. New and interesting desmids from the Southeastern United States. Acta Soc. Sci. Fenn., n.s., B. 2: 1-62.

Scott, A.M., R. Grönblad \& H.T. Croasdale. 1965. Desmids from the Amazon basin, Brasil, collected by Dr. H. Sioli. Acta Bot. Fennica, 69: 1-94.

Scott. A.M. \& G.W. Prescott. 1958. Some freshwater algae from Arnhem land in the Northern Territory of Australia. Records American-Australia Sci. Exped. Arnhem Land 3. 8-136, Pls 1-29, 1 Map, Melborne University Press.

Scott. A.M. \& G.W. Prescott. 1961. Indonesian Desmids, Hydrobiologia, 17(1/2): 1-132.

Sinha, J.P. \& G.D. Mishra. 1967. Some desmids from Ranchi. Phykos, 6: 102-105.

Smith, G.M. 1924. Phytoplankton of the island lakes of Wisconson. Part II. Desmidiaceae. Bull. Wisc. Geol. Nat. Hist. Surv., 57(ii): 1-227.

S.P.D.C. 1988. Shell Petroleum Development Company, Western Division, Warri Nigeria. (Personal communication).

Suxena, M.R. \& V. Venkateswarlu. 1970. Desmids of Andhra Pradesh. V. Mostly from Warangal and its environs. Phykos, 9: 17-28.

Thomasson, K. 1957. Notes on the plankton of Lake Bangweulu. Nova Acta Reg. Soc. Sci. Upsal. Ser. 4, 17(3): $1-18$.

Thomasson, K. 1960. Notes on the plankton of Lake Bangweulu. Part 2. Nova Acta Soc. Sci. Upsal. Ser. 4 17(12): 1-43.

Thomasson, K. 1963. Araucanian Lakes. Plankton Studies in North Patagonia, with notes on terrestrial vegetation. Acta Phytogeogr. Suecica, 47: 1-139, 47 figs.

Thomasson, K. 1965. Notes on algal vegetation of Lake Kariba. Nova Acta Soc. Sci. upsal., Ser. 4, 19(1): 1-34.

Thomasson, K. 1966. Phytoplankton of Lake Shiwa Ngandu. Expl. Hydrobiol. Bangweolo-Luapula. IV. Fas. 2: 1-90, 21 Pls.

Thomasson, K. 1967. Phytoplankton from Lakes on Mt. Wilhelm, East New Guinea. Blumba, 15(2): 285-296.

Thomasson, K. 1971. Amazonian algae. Mem. Inst. Roy. Sci. Nat. Beig., Ser. 2, 86: 1-57.

Thomasson, K. 1973. Notes on the plankton of some Sydney reservoirs, with description of two interesting desmids. Contr. N.S.W. Nat. Herb., 4: 344-394.
Turner, W.B. 1892. Algae aquae dulcis Indiae orientalis. The freshwater algae (principally Desmidiaceae) of East India. Kongl. Svenska Vet. Acad. Handl., 25(5): 1-187.

Vidyavati \& J. Nizam. 1970. Conjugation studies in Euastrum spinulosum Delp. var. duplominor. Phykos, 9: 139-147.

Wallich, G.C. 1860. Descriptions of Desmidiaceae from Lower Bengal. Ann. Mag. Nat. Hist., 111(5): 184-197.

West, G.S. 1907. Report on the freshwater algae, including phytoplankton of the Third Tanganyikan Expedition, conducted by Dr. W.A. Cunnington, 1904-1905. Journ. Linn. Soc. (Bot.), 38: 81-197.

West, T. 1860. Remarks on some Diatomaceae new or imperfectly described and on a new Desmid. Trans. Roy. Microsc. Soc., II, 8: 147-153, Pls 7:16.

West, W. 1890. Contribution to the freshwater algae of North Wales. Journ. Roy. Microsc. Soc., 6: 277-306, Pls 5, 6.

West, W. 1892. A contribution to the freshwater algae of North Ireland. Journ. Linn. Soc. Bot., London, 29: 103216.

West, W. \& G.S. West. 1895. A contribution to our knowledge of the freshwater algae of Madagascar. Trans. Linn. Soc. London, Bot. Ser. 5 (2): 41-90, Pls. 5-9.

West, W. \& G.S. West. 1896. On some North American Desmids. Trans. Linn. Soc. Bot., Ser. 2, 5: 229-294.

West, W. \& G.S. West. 1902. A contribution to the freshwater algae of Ceylon. Trans. Linn. Soc. Lond., Ser. 11(6): 123215.

West, W. \& G.S. West. 1904. A monograph of the British Desmidiaceae. Vol. 1, xxxvi + 224 pp., 32 Pls. Ray Society, London.

West, W. \& G.S. West. 1912. On the periodicity of the phytoplankton of some British Lakes. Journ. Linn. Soc. (Bot.), 40.

West, W., G.S. West \& N. Carter. 1904-1923. A monograph of the British Desmidiaceae. Vol. V., The Ray Society, London.

Wittrock, W.B. 1869. Anteckningar om Skandinaviens desmidiéer, Nova Acta Soc. Sci. Upsala, 3(7): 2-72.

Wolle, F. 1881. American freshwater algae. VI. Bull. Torrey Bot. Club, 8: 1-4.

Wolle, F. 1882. Freshwater algae. VI. Bull. Torrey Bot. Club, 9(3), 25-30, P1. 13.

Wolle, F. 1892. Desmids of the United States and List of American Pediastrums. Bethlehem. $\mathrm{Pa}$ 2nd. ed.: $169 \mathrm{pp}$.

Yacubson, S. 1973. El Fitoplankton de la laguna de san Javier del Valle (Esta Merida) Venezuela. Rev. Alg. N.S., 11: 91131. 